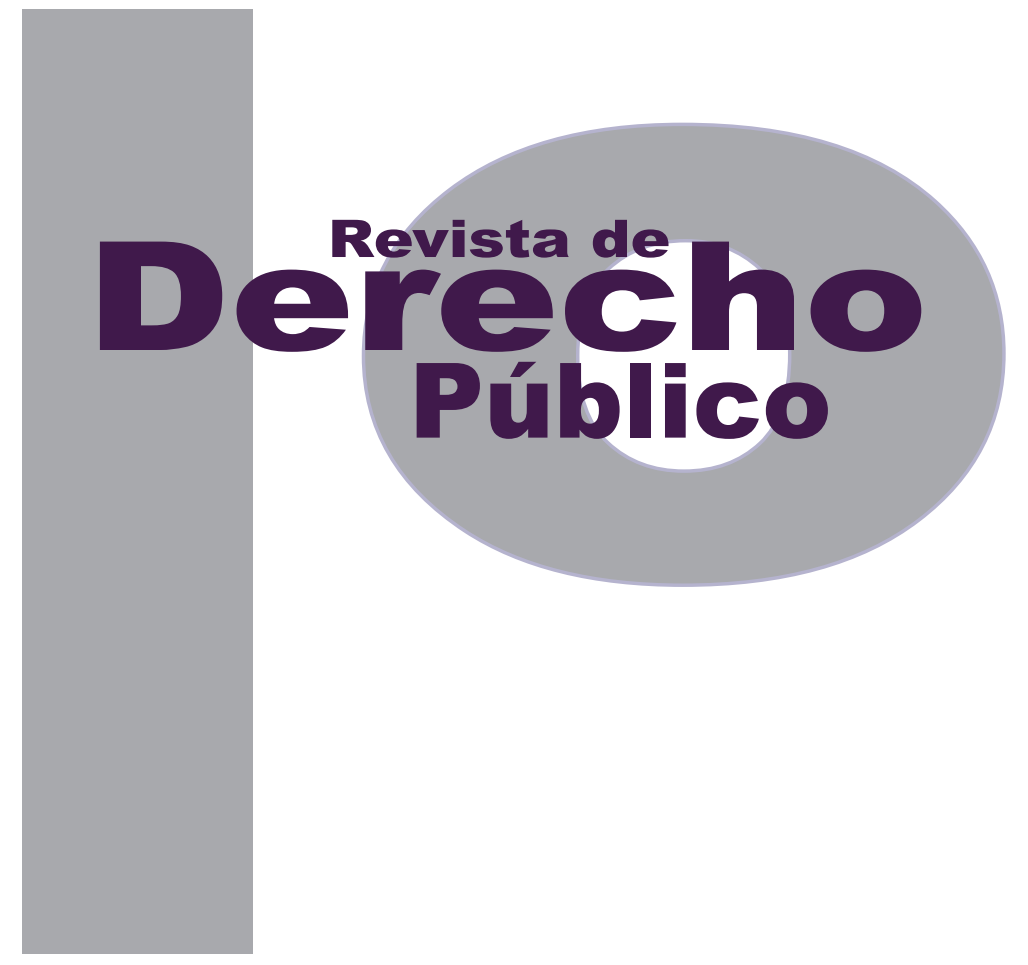

\title{
LAS CONTROVERSIAS EN EL DERECHO INTERNACIONAL AMBIENTAL Y LOS RETOS EN LA APLICACIÓN DEL PRINCIPIO DE PRECAUCIÓN EN EL ÁMBITO LOCAL
}

\author{
PaOla AndRea SANTANA Plata
}

Universidad de los Andes

Facultad de Derecho

Revista de Derecho Público N. ${ }^{\circ} 30$

Enero - Junio de 2013. ISSN 1909-7778 


\title{
Las controversias en el derecho internacional ambiental y los retos en la aplicación del principio de precaución en el ámbito local
}

\author{
Paola Andrea Santana Plata*
}

\begin{abstract}
RESUMEN
El principio de precaución es uno de los conceptos más flexibles del derecho internacional, pues adquiere distintos significados dentro de los dispositivos que lo consagran, y sus mecanismos de activación cambian según los niveles de riesgo y de restricción normativa de cada contexto. En Colombia, la Constitución, unas pocas leyes ambientales y la jurisprudencia de las altas Cortes lo han aplicado en relación con temas como derechos colectivos, residuos, diversidad biológica, minería, etc. El presente trabajo pretende explicar el alcance de este principio, considerando sus elementos negativos y positivos a partir del análisis de sus orígenes en el derecho internacional y la manera como ha sido implementado en el ordenamiento jurídico colombiano.
\end{abstract}

Palabras clave: principio de precaución, derecho internacional ambiental, principio de prevención, derecho ambiental colombiano, Constitución ecológica, jurisprudencia ambiental.

\begin{abstract}
The Precautionary Principle is one of the most flexible concepts of International Environmental Law because of its different meanings within the devices that contain it and its diverse activation mechanisms depending on risk levels and rules of restriction. In Colombia, the Constitution, a few environmental laws and jurisprudence of the high courts have applied it in relation to issues such as collective rights, waste, biodiversity, mining, etc. This paper aims to explain the scope of this principle considering its negative and positive elements from the analysis of its origins in International Law and the way it has been implemented in Colombian legal system.
\end{abstract}

KeY WORDS: Precautionary Principle, International Environmental Law, Principle of Preventive Action, Colombian Environmental Law, Ecological Constitution, Environmental Jurisprudence. 


\section{SUMARIO}

Introducción - I. ANTECEDENTES Y GENERALIDADES DEL PRINCIPIO DE PRECAUCIÓN - A. Orígenes del principio de precaución en el Derecho Internacional Ambiental - B. Detrás del concepto de precaución: La importancia del lenguaje - 1. La consagración del principio en los acuerdos multilaterales ambientales y su relación con el comercio - 2. Diferencias entre el principio de precaución y la prevención - 3 . Los límites del principio - II. INCORPORACIÓN DEL PRINCIPIO DE PRECAUCIÓN AL DERECHO AMBIENTAL COLOMBIANO - A. La constitución ecológica de 1991 - B. El principio de precaución en las principales leyes ambientales - 1. La ley 99 de 1993 y un nuevo paradigma ambiental - 2. Régimen sancionatorio - 3. Licenciamiento ambiental - III. DE LA TEORÍA A LA PRÁCTICA: JURISPRUDENCIA SOBRE EL USO DEL PRINCIPIO DE PRECAUCIÓN EN COLOMBIA - IV. CONCLUSIONES - Bibliografía. 
Introducción

La preocupación por el medio ambiente y la ecología surge de manera clara en los años setenta, en un contexto mundial en el que abundaban los movimientos sociales (Flórez, 2000). Fue entonces cuando aparecieron las primeras perspectivas teóricas a la crítica de la modernidad en el pensamiento occidental en torno a la sobreexplotación de recursos naturales por parte del hombre y los desastres derivados de esta. La deforestación, el cambio climático, la creciente contaminación, las especies en peligro de extinción y los riesgos derivados de la manipulación genética de los seres vivos, han suscitado cada vez más debates en torno a la problemática de conservación ecológica cuya vigencia es hoy, más importante que nunca.

Desde finales del siglo xIx y principios del xx la sociedad occidental ha construido la perspectiva de la naturaleza salvaje en torno a un concepto particular de ambientalismo. Gracias a la expansión tecnológica y comercial, los ecosistemas mundiales sufrieron en esta época transformaciones aceleradas (Cajicas, s. f.). Esto, por cuanto las ciencias sociales y el derecho han intentado describir el término medio ambiente relacionándolo con la evocación al entorno natural, teniendo en cuenta al ser humano como destinatario o protagonista (Federovisky, 2007): la naturaleza posee una dimensión social que obliga a incorporar al hombre en calidad de perturbador y no de observador, puesto que somos nosotros los que modificamos las características originales del entorno para hacer de él nuestro hogar, encontrar los medios de supervivencia o extraer productos.

A partir de todas esas consideraciones es claro que la preocupación por el ambiente no es un tema nuevo. Por el contrario, se encuentra en un proceso de configuración formal a partir de la identificación de las inquietudes más trascendentes, los debates a los que se somete, los principios y criterios que dan forma a las soluciones y la consolidación de normas de carácter supranacional que funcionan como lineamientos para los países, imponiéndoles derechos y obligaciones.

Entonces, teniendo en cuenta que el ser humano no es un sujeto pasivo sino que su relación con el medio ambiente está determinada en gran medida por él mismo - sin descartar de plano el elemento del azar o los cambios habituales en la biósfera-, este escrito no pretende, de ninguna manera, ser un análisis neutral frente a un problema legal cuya solución ha sido justificada en términos de protección al medio ambiente. En aras de comprender uno de las aspectos más llamativos de la legislación implementada en Colombia en torno al tema ambiental, este texto tiene como propósito explicar al empresario que desarrolla su actividad económica en nuestro país el alcance del principio de precaución, con sus elementos negativos y positivos, a partir del análisis de sus orígenes en el derecho internacional ambiental y la manera como ha sido implementado en el ordenamiento jurídico colombiano.

Como se observa, el objeto de estudio de este trabajo es el principio de precaución, conocido 
como el enfoque contenido en el principio 15 de la Declaración de Río que establece: "Con el fin de proteger el medio ambiente, los Estados deberán aplicar ampliamente el criterio de precaución conforme a sus capacidades. Cuando haya peligro de daño grave o irreversible, la falta de certeza científica absoluta no deberá utilizarse como razón para postergar la adopción de medidas eficaces en función de los costos para impedir la degradación del medio ambiente". De allí se derivan varias preguntas que son las que han impulsado la preocupación principal de este trabajo: ¿cómo saber que realmente hay un riesgo medioambiental significativo que quepa dentro del concepto de daño grave e irreversible?, ¿qué significa que haya falta de certeza científica absoluta?, ¿cómo calcular los costos medioambientales ante la falta de certeza científica?, y muchas otras inquietudes más que resultan de la peculiar redacción del mencionado principio 15 o enfoque de precaución.

Pero antes de entrar en detalle respecto a las hipótesis, metodología y alcances de este trabajo, es preciso indicar que uno de los grandes problemas del derecho ambiental, y en general de todo lo relacionado con nuestro entorno natural, es que existe en ello una fuerte e innegable influencia por parte de los movimientos sociales, que tiene dos consecuencias prácticas. La primera, es aquella defendida principalmente por los actores más tradicionales o conservadores que piensan el tema ambiental como una moda posmodernista que carece de mayor fundamento teórico y práctico. La segunda, se encuentra relacionada con esa idea perjudicial de que las normas y la regulación estricta son la salvación para todos los problemas ambientales del planeta.

Teniendo en cuenta lo anterior, la aproximación al objeto de estudio se realizará de manera tal que no se beneficie un extremo ni el otro. Si bien lo más sencillo sería tomar partido y defender las bondades o los perjuicios de este concepto tal como ha sido entendido a nivel internacional y en Colombia, considero pertinente dejar de lado los prejuicios tradicionales que podrían empañar el análisis jurídico del principio.

Entonces, la inquietud que da origen a la investigación que a continuación se desarrolla, es aquella que pretende desenmarañar, al menos en una pequeña proporción, el entramado del ordenamiento jurídico colombiano en lo concerniente al principio de precaución. Para hacerlo, se utilizarán diversas estrategias metodológicas que parten principalmente del examen de fuentes primarias, tales como los textos de los tratados internacionales ambientales y las leyes y sentencias promulgadas a propósito de los primeros. Al mismo tiempo, se consultarán libros, artículos y demás publicaciones que completarán la bibliografía. Lo anterior, pues habrá que tener en cuenta la distinción metodológica existente entre aquellas bases documentales que constituyen los primeros asentamientos de información disponible para la realización de la presente investigación (fuentes de primera mano) y los trabajos críticos elaborados por otras personas que ya tienen incluida una línea argumentativa, que bien puede ser diferente a la presentada en este escrito, por lo que constituyen fuentes de segunda mano. Así las cosas, 
"el concepto de "primera" y "segunda mano" depende del sesgo que se dé a la tesis" (Eco, 2001). Como lo que se busca es no tanto discutir las hipótesis existentes sino entender el sentido de algunas regulaciones, se hace necesario recurrir directamente a estas y en menor medida a artículos escritos sobre ellas.

Sin embargo, el análisis del principio de precaución exige también la utilización de un método comparativo que permita definirlo en contraposición a otros principios del derecho internacional ambiental, como lo es el de prevención. Además, podría considerarse que como consecuencia de la multiplicidad de escenarios y de instrumentos en los cuales se ha hecho referencia a este principio, es conveniente identificar sus matices. Es en estos escenarios en donde se discutirá la importancia del lenguaje como determinador de los límites y posibilidades de la aplicación material del concepto, pues tal como ha sido introducido por los diversos mecanismos internacionales en la agenda ambiental, la interpretación del principio dependerá de las palabras utilizadas para definirlo. Si bien la idea en este escrito no es realizar un resumen pormenorizado de la definición de precaución en cada uno de esos instrumentos, sí lo es la realización de un paralelo entre las palabras que componen el lenguaje.

Finalmente, para alcanzar el propósito trazado para esta investigación, están las fuentes primarias locales, que consisten fundamentalmente en una muestra de algunas sentencias que serán organizadas en una línea jurisprudencial sencilla en donde se describa la utilización del principio de precaución.
Nótese que en la descripción de fuentes mencionadas anteriormente brillan por su ausencia los Actos Administrativos del Ministerio de Ambiente y Desarrollo Sostenible y de las Corporaciones Autónomas Regionales. Dicha omisión es completamente intencional y se fundamenta no solo en que incluirlos implicaría extender este escrito más allá de los límites que razonablemente se han trazado para cumplir con el objetivo general, sino porque, además, esta mixtura resultaría extenuante tanto para quien escribe como para quien lee. Especialmente, si se tiene en cuenta que en virtud del principio de rigor subsidiario cada autoridad ambiental aplica normas sucesiva y respectivamente más rigurosas "en la medida en que se desciende en la jerarquía normativa y se reduce el ámbito territorial de las competencias, cuando las circunstancias locales así lo ameriten..." (art. 63, Ley 99/93).

Vista la metodología planteada, en aras de expresar con mayor claridad los objetivos específicos trazados en este trabajo, basta mencionar que lo que se busca es, en primer lugar, identificar los orígenes del principio de precaución en el derecho internacional ambiental y los términos en los que ha sido definida su aplicación para las relaciones entre Estados. También se analizará el significado del concepto de precaución tomando como punto de partida las definiciones contempladas en estos instrumentos, al tiempo que se dará una mirada breve pero transversal a las disputas que suscita en materia comercial. Lo anterior, con el ánimo de dar paso a la determinación de cómo ha sido la introducción de este principio en el derecho am- 
biental colombiano a través de su consagración constitucional, legal y jurisprudencial.

A continuación, se comenzará entonces con el estudio de los orígenes y las generalidades del principio de precaución en el ámbito internacional.

\section{ANTECEDENTES Y GENERALIDADES DEL PRINCIPIO DE PRECAUCIÓN}

En este capítulo se tratará de manera general el origen del principio de precaución en el derecho ambiental internacional. Al respecto, no bastará solamente con identificar las primeras veces en las cuales fue utilizado, sino que además es importante señalar los contextos en los cuales se desarrolló y el significado que gracias a ello adquiere en determinados momentos. Esto, a propósito de la flexibilidad del principio, que no tiene necesariamente un significado preciso y que, por el contrario, se muestra cambiante de conformidad con las circunstancias y el alcance dado por el mecanismo que lo desarrolla.

Entonces, la necesidad de acudir al principio de precaución no es igual en todos los dispositivos internacionales ni se activa cuando existe el mismo nivel de riesgo y de la misma manera, las medidas que se toman al respecto tienen distintos niveles de restricción. Además, el cuerpo del derecho internacional que se relaciona con este tema no se compone únicamente de tratados, ya que la doctrina y la jurisprudencia también han discutido ampliamente la posibilidad de que la precaución sea una costumbre internacional y los inconvenientes que este concepto puede traer para el comercio.

\section{A. Orígenes del principio de precaución en el derecho internacional ambiental}

La mayoría de los trabajos realizados sobre el origen del principio de precaución coinciden en que este fue utilizado por primera vez, de manera local, en las leyes alemanas relativas a la política ambiental municipal (Sans, 2003, p. 10). Se ha señalado, además, que en algunas de las decisiones de tribunales americanos relativas al medio ambiente y en la legislación europea también se hizo alguna aproximación al concepto de precaución (Actas de la Mesa Redonda de la Geneva Environment Network, 2002).

Entonces, el principio empezó a ser mencionado en el ámbito nacional antes que en el internacional, pues fue solo a finales del siglo xIx que Ios Estados comenzaron a reconocer las consecuencias transfronterizas de las actividades que afectaban áreas más allá de la jurisdicción nacional, tales como la contaminación de ríos compartidos o la destrucción de la vida salvaje (Sans, 2003, p. 4). A partir de allí la comunidad internacional ha entendido que una buena proporción de las regulaciones en materia ambiental se encuentran influenciadas por factores extra legales como la ciencia, la economía y otros valores cuya consideración es indispensable a la hora de tomar decisiones que intentan proteger el medio ambiente. Así por ejemplo, la aproximación científica al medio ambiente se ha realizado a través de categorías que incorporan, además, conceptos económicos y culturales como cambio climático, residuos peligrosos, biodiversidad, entre muchos más. 
Lo anterior, en armonía con el concepto de desarrollo sostenible del que se habló por primera vez en la Comisión Brundtland de 1987 (Sans, 2003, p. 10) y según el cual la humanidad deberá encontrar una manera de suplir las necesidades del presente sin comprometer los recursos que permitirían a las generaciones futuras proveerse las propias.

La incertidumbre, o como lo ha expresado el texto del principio 15 de la Declaración de Río, la falta de certeza científica en torno a algunas actividades humanas, que se relaciona con la incapacidad de predecir los posibles daños que afectarán al ambiente como consecuencia de dichas acciones, ha despertado en la comunidad internacional la determinación de impulsar la toma de decisiones en pro de la conservación aún sin conocer en definitiva el nivel de riesgo ni las condiciones adecuadas para la protección frente a consecuencias que no han ocurrido. La certeza científica en cuanto a la medición del daño potencial se ve empañada muchas veces porque los fenómenos del mundo natural acogen en mejor proporción la escala de la larga duración y son menos trascendentes los acontecimientos naturales que puedan identificarse de manera especial con una determinada coyuntura, siendo mucho más raros aquellos que responden a la temporalidad propia del acontecimiento.

Así las cosas, surgió en el derecho internacional ambiental el impulso por utilizar un mecanismo que permitiera el accionar de los Estados y los sujetos de derecho frente a los peligros inminentes, antes de que fuera necesaria la prue- ba científica de su potencial dañino para con el entorno natural global. Este impulso se materializaría a través de instrumentos de naturaleza vinculante (Hard law) y de otros no vinculantes (Soft law). La gran diferencia entre ambos es que el primer tipo hace referencia a pactos, convenios o tratados que obligan a los Estados a cumplir ciertos deberes bajo el derecho internacional, mientras que los segundos trazan metas para el futuro o determinan estándares de buen comportamiento y Due Diligence en un contexto de cooperación internacional y a través de recomendaciones, resoluciones de organizaciones internacionales, entre otros mecanismos.

Quizá uno de los primeros instrumentos con efectos transfronterizos en hablar de precaución fue el Convenio internacional relativo a la intervención en alta mar en caso de accidentes que causen contaminación por hidrocarburos, firmado en Bruselas el 29 de noviembre de 1969, en el cual los artículos I inciso primero y V establecen las bases para la justificación de la necesidad de actuar ante la falta de certeza del daño y frente al temor de las consecuencias de una omisión.

El siguiente gran antecedente que cambió la perspectiva tradicional de la obligación de probar la causal del daño antes de tomar medidas protectoras del ambiente fue el Convenio de París de 1974 para la prevención de la contaminación marina de origen terrestre, que en su artículo 4 estimula a las partes a tomar medidas para evitar la contaminación. Así mismo, la Convención de Viena para la protección de la capa de ozono, de 1985, menciona en su preámbulo 
las medidas de precaución que se han tomado para alcanzar este objetivo. Ha de reconocerse que este es el primer instrumento internacional en utilizar la palabra precaución y no solamente referirse a la prevención.

Años después, en 1987, el Protocolo de Montreal relativo a las sustancias que agotan la capa de ozono reconoce el rol del análisis científico y demás aspectos técnicos y económicos en la búsqueda del desarrollo sostenible y la necesidad apremiante de tomar medidas para proteger el ambiente.

Por su parte, el preámbulo de la Convención sobre la diversidad biológica y el principio 15 de la Declaración de Río terminan de instituir la idea de precaución, como el fundamento a partir del cual los Estados podrán tomar medidas para evitar o disminuir las amenazas o peligros al medio ambiente a través de la toma de decisiones que implican actos tendientes a su protección, pese a la falta de pruebas científicas inequívocas. Esto, a propósito de los riesgos que implicaría la omisión de salvaguardar el entorno ante una determinada actividad humana cuyos efectos se desconocen.

Además de los instrumentos anteriormente mencionados, el derecho internacional cuenta con una larga lista de convenios y herramientas no vinculantes que hacen referencia al principio de precaución, dentro de los cuales se encuentran el preámbulo de la Declaración de La Haya (1990); el artículo 2 del Convenio sobre la protección y utilización de los cursos de agua transfronterizos y de los lagos internacionales (1992); el artículo 3 de la Convención sobre el cambio climático (1992); el artículo 5 del Acuerdo sobre la aplicación de medidas sanitarias y fitosanitarias (1993); el preámbulo y los artículos 1, 10 y 11 del Protocolo de Cartagena (2000); el preámbulo y los artículos 1 y 8 del Convenio de Estocolmo (2001); entre otros.

Tal como se mencionó en párrafos anteriores, las decisiones de los tribunales internacionales también han hecho referencia a la precaución pero no necesariamente le han reconocido el carácter de principio. Dos de los más importantes casos sobre el particular han sido, el relativo a las medidas tomadas por la Comunidad Europea que afectan la carne y los productos derivados, también conocido como el caso Hormonas, y el del atún de aleta azul del sur (омc, 1998).

En el primero de ellos, Estados Unidos y Canadá se enfrentaron en contra de las medidas de precaución de la Comunidad Europea que prohibió las importaciones de carne y productos derivados del ganado bovino al que se le hubiesen administrado hormonas, con fundamento en la protección de la salud humana. Ya que no existía prueba del daño, el Órgano de Apelación de la omc decide que si bien los Estados tienen derecho a tomar decisiones protectoras cuando hay riesgo de daños irreversibles, estas deben ser provisionales y no permanentes.

En el otro caso, Australia y Nueva Zelanda se enfrentaron a Japón por la disminución de especímenes de atún de aleta azul del sur, con el argumento de que era necesario tomar medidas prudenciales y de precaución para evitar un daño grave a la especie. La decisión final del tribunal, en este caso, fue igual a la anterior en el sentido 
de admitir medidas provisionales, pero reconociendo que ante la falta de certeza científica no se pueden vulnerar los derechos de las partes.

Otro ejemplo significativo de controversia llevada a los tribunales, a propósito de la aplicación del principio de precaución, es el de Ecuador contra Colombia ante la Corte Internacional de Justicia, por la fumigación aérea de herbicidas tóxicos en lugares cercanos a la frontera. No obstante, dicha discusión está lejos de zanjarse pues en este caso no solamente hay estudios científicos contradictorios en torno a la toxicidad del glifosato, que implica discutir si hay ausencia total de certeza científica o no, sino porque también se cuestionan las características biológicas de la región y por lo tanto el nivel de protección que se requiere para evitar cualquier peligro de daño grave o irreversible. Esto, sumado a que las partes invocan, además, otros argumentos relacionados con distintos principios de derecho internacional como la soberanía de los pueblos y asuntos como la competencia jurisdiccional de Corte.

De conformidad con todo lo anterior, la doctrina internacional ha aceptado que el estatus jurídico del principio de precaución se encuentra evolucionando (Sans, 2003, p. 279). A partir de las decisiones judiciales, de su consagración en los distintos tratados y de las prácticas de los Estados, se puede concluir que la aceptación de este principio no ha sido uniforme ni lo será por algún tiempo. Por ejemplo, puede considerarse que en el marco de la Comunidad Europea la precaución goza del estatus de costumbre internacional, mientras que los tribunales e insti- tuciones internacionales como la Organización Mundial del Comercio y el Tribunal Internacional del Derecho del Mar se han negado a reconocerlo en estos términos, teniendo en cuenta la oposición reiterada de algunos Estados.

Comúnmente ha llegado a afirmarse que, por ejemplo, Europa acepta el principio de precaución pero Estados Unidos no (Sunstein, 2009).

Estas aseveraciones resultan razonables a la luz del hecho de que los estadounidenses parecen estar comparativamente despreocupados acerca de los riesgos relacionados con el calentamiento global y la modificación genética de los alimentos; en estos contextos, los europeos favorecen las precauciones, mientras que los estadounidenses requerirían algo parecido a una prueba de peligro. Por cierto, el asunto es totalmente diferente en el contexto de las amenazas a la seguridad nacional (Sunstein, 2009 p. 215).

Por ello, cada país tiene su manera particular de atender los riesgos que considera más peligrosos o prioritarios y de exigir pruebas antes de tomar medidas para mitigarlos. Por supuesto, estas precauciones podrían ser potencialmente costosas para la economía o para otros ámbitos de la vida social.

De allí que la trascendencia del principio deberá ser determinada caso a caso y por eso las Cortes y tribunales internacionales han sido renuentes al tratamiento expreso del principio de precaución como costumbre internacional (Sans, 2003, p. 279). Sin embargo, en lo que sí se puede considerar que existe un acuerdo es en cuanto a las características de la precau- 
ción como un estándar para evaluar la validez de algunas leyes, interpretarlas y llenar vacíos normativos (Unesco, Comest, 2005).

\section{B. Detrás del concepto de precaución: la importancia del lenguaje}

El Diccionario de la Real Academia de la Lengua Española define la precaución como la "reserva, cautela para evitar o prevenir los inconvenientes, dificultades o daños que pueden temerse". Sin embargo, en el marco de las regulaciones de derecho internacional relativas a diversos temas, el concepto ha sido utilizado de muchas formas y con un rango de aplicación variado. Adicionalmente, su contenido ha sido confundido con el principio de prevención cuyo significado se relaciona con la "preparación y disposición que se hace anticipadamente para evitar un riesgo o ejecutar algo" (RAE, S. f.). Por ello, en esta sección se discute la importancia del lenguaje utilizado en los diversos mecanismos para definir o consagrar el principio de precaución, así como las consecuencias que esto tiene al momento de su aplicación práctica en los distintos escenarios posibles.

\section{La consagración del principio en los acuerdos multilaterales ambientales y su relación con el comercio}

Tratándose de un concepto tan complejo como el de la precaución, es indispensable reconocer que se compone de varios elementos. Además de la preocupación por regular acontecimientos que no han ocurrido pero que pueden llegar a ocurrir como consecuencia de una actividad que potencial o probablemente tenga un impacto negativo para el ambiente, el principio incluye palabras como riesgo, daño e incertidumbre científica. Estas, según las provisiones de los mecanismos que las contienen, pueden variar de un grado a otro de exigencia para la activación del principio que conlleva la intervención de los Estados y los efectos más o menos restrictivos de estos. A continuación, en la tabla 1, se expondrán algunos ejemplos de la manera como el principio de precaución es entendido en ciertos instrumentos internacionales. 
Tabla 1: Elementos del principio de precaución en

algunos instrumentos internacionales

\begin{tabular}{|c|c|c|c|c|}
\hline \multirow{2}{*}{$\begin{array}{l}\text { Instrumento y defini- } \\
\text { ción de precaución }\end{array}$} & \multicolumn{3}{|c|}{ Identificación de la precaución } & \multirow{2}{*}{$\begin{array}{l}\text { Relación con el prin- } \\
\text { cipio } 15 \text { de Río }\end{array}$} \\
\hline & Riesgo & Daño & $\begin{array}{l}\text { Incertidumbre } \\
\text { científica }\end{array}$ & \\
\hline $\begin{array}{l}\text { Convenio internacional } \\
\text { relativo a la interven- } \\
\text { ción en alta mar en caso } \\
\text { de accidentes que cau- } \\
\text { sen contaminación por } \\
\text { hidrocarburos [1969]. } \\
\text { ARTícULO 1. Las Partes } \\
\text { del presente Convenio } \\
\text { podrán tomar en alta } \\
\text { mar las medidas nece- } \\
\text { sarias para prevenir, mi- } \\
\text { tigar o eliminar todo pe- } \\
\text { ligro grave e inminente } \\
\text { contra su litoral o intere- } \\
\text { ses conexos, debido a la } \\
\text { contaminación o ame- } \\
\text { naza de contaminación } \\
\text { de las aguas del mar por } \\
\text { hidrocarburos. }\end{array}$ & $\begin{array}{l}\text { "Peligro grave e in- } \\
\text { minente contra su } \\
\text { litoral o intereses } \\
\text { conexos" cuando } \\
\text { ocurran hechos a los } \\
\text { que le sean "razona- } \\
\text { blemente atribuibles } \\
\text { consecuencias desas- } \\
\text { trosas de gran magni- } \\
\text { tud" }\end{array}$ & $\begin{array}{l}\text { Contaminación o } \\
\text { amenaza de contami- } \\
\text { nación de las aguas } \\
\text { del mar por hidro- } \\
\text { carburos, resultante } \\
\text { de un accidente ma- } \\
\text { rítimo u otros actos } \\
\text { relacionados con ese } \\
\text { accidente. }\end{array}$ & No se menciona & $\begin{array}{l}\text { i) No menciona la } \\
\text { precaución sino la } \\
\text { adopción de medi- } \\
\text { das "preventivas". } \\
\text { (ii) No hace referen- } \\
\text { cia al conocimiento } \\
\text { científico para de- } \\
\text { terminar el nivel de } \\
\text { riesgo o la gravedad } \\
\text { del daño. }\end{array}$ \\
\hline $\begin{array}{l}\text { Convenio de París para } \\
\text { la prevención de la con- } \\
\text { taminación marina de } \\
\text { origen terrestre [1974]. } \\
\text { ARTíCULO 1: "Adoptar } \\
\text { todas las medidas po- } \\
\text { sibles para impedir la } \\
\text { contaminación del mar". } \\
\text { ARTíCULO 5: "Las Partes } \\
\text { Contratantes se obligan } \\
\text { a adoptar medidas des- } \\
\text { tinadas a prevenir y, en } \\
\text { su caso, eliminar la con- } \\
\text { taminación de origen } \\
\text { terrestre". ARTíCULO 8: } \\
\text { "Nada de lo dispuesto en }\end{array}$ & $\begin{array}{l}\text { ARTícULO 1: peligro } \\
\text { para la salud huma- } \\
\text { na, perjudicar los } \\
\text { recursos vivos y el } \\
\text { sistema ecológico, } \\
\text { reducir las posibilida- } \\
\text { des de esparcimiento } \\
\text { u obstac ulizar otros } \\
\text { usos legítimos de los } \\
\text { mares. }\end{array}$ & $\begin{array}{l}\text { ARTíCULO } 3 \text { LITERAL } \\
\text { C: se entiende por } \\
\text { "contaminación te- } \\
\text { rrestre" la contami- } \\
\text { nación de la zona ma- } \\
\text { rítima causada: i) por } \\
\text { los cursos de agua, } \\
\text { ii) a partir de la costa, } \\
\text { incluida la introduc- } \\
\text { ción por medio de } \\
\text { canalizaciones sub- } \\
\text { marinas y otras cana- } \\
\text { lizaciones, iii) a partir } \\
\text { de estructuras artifi- } \\
\text { ciales situadas bajo la }\end{array}$ & $\begin{array}{l}\text { Si bien no se } \\
\text { menciona la } \\
\text { incertidumbre } \\
\text { científica, en el } \\
\text { artículo } 10 \text { sí se } \\
\text { hace referencia } \\
\text { a "programas } \\
\text { complementa- } \\
\text { rios o conjuntos } \\
\text { de investigación } \\
\text { científica y téc- } \\
\text { nica, incluida la } \\
\text { investigación de } \\
\text { los mejores mé- } \\
\text { todos de elimi- } \\
\text { nación o de sus- }\end{array}$ & $\begin{array}{l}\text { (i) No menciona la } \\
\text { precaución sino la } \\
\text { adopción de medidas } \\
\text { preventivas, (ii) pese } \\
\text { a que no se refiere } \\
\text { a la falta de certeza } \\
\text { científica, sí resalta la } \\
\text { necesidad de contar } \\
\text { con investigaciones } \\
\text { de este tipo como } \\
\text { medio para alcanzar } \\
\text { el fin propuesto por } \\
\text { el convenio. }\end{array}$ \\
\hline
\end{tabular}




\begin{tabular}{|c|c|c|c|c|}
\hline $\begin{array}{l}\text { el presente Convenio } \\
\text { puede ser interpretado } \\
\text { en el sentido de impedir } \\
\text { a las Partes Contratantes } \\
\text { la adopción de medidas } \\
\text { más estrictas en relación } \\
\text { con la lucha contra la } \\
\text { contaminación marina de } \\
\text { origen terrestre" }\end{array}$ & & $\begin{array}{l}\text { bajo la jurisdicción de } \\
\text { una Parte Contratante } \\
\text { dentro de los límites } \\
\text { de la zona de aplica- } \\
\text { ción del presente Con- } \\
\text { venio. }\end{array}$ & $\begin{array}{l}\text { titución de sus- } \\
\text { tancias nocivas, } \\
\text { para conseguir } \\
\text { una disminución } \\
\text { de la contami- } \\
\text { nación marina } \\
\text { de origen terres- } \\
\text { tre". }\end{array}$ & \\
\hline $\begin{array}{l}\text { Convención de Viena } \\
\text { para la protección de la } \\
\text { capa de ozono [1985]. } \\
\text { ARTíCULO 2, NUMERAL 2: } \\
\text { “Adoptarán las medidas } \\
\text { legislativas o administra- } \\
\text { tivas adecuadas y coope- } \\
\text { rarán en la coordinación } \\
\text { de las políticas apropia- } \\
\text { das para controlar, limi- } \\
\text { tar, reducir o prevenir } \\
\text { las actividades humanas } \\
\text { bajo su jurisdicción”. }\end{array}$ & $\begin{array}{l}\text { En lugar de hablar de } \\
\text { riesgos se refiere en } \\
\text { el artículo } 1 \text { a todos } \\
\text { los cambios en el me- } \\
\text { dio físico con posibles } \\
\text { efectos adversos para } \\
\text { el clima y los biomas. }\end{array}$ & $\begin{array}{l}\text { adversos } \\
\text { "efectos } \\
\text { como resultado de la } \\
\text { modificación o pro- } \\
\text { bable modificación } \\
\text { de la capa de ozono" }\end{array}$ & $\begin{array}{l}\text { ARTíCULO } \\
\text { NUMERAL } \\
\text { "La aplicación } \\
\text { de este artículo } \\
\text { se basará en las } \\
\text { consideraciones } \\
\text { científicas y téc- } \\
\text { nicas pertinen- } \\
\text { tes". ARTícULO } \\
3 \text { "Las Partes } \\
\text { se comprome- } \\
\text { ten, según pro- } \\
\text { ceda, a iniciar } \\
\text { investigaciones } \\
\text { y evaluaciones } \\
\text { científicas y a } \\
\text { cooperar en su } \\
\text { realización, di- } \\
\text { rectamente o } \\
\text { por conducto } \\
\text { de órganos in- } \\
\text { ternacionales } \\
\text { competentes". } \\
\text { ARTículO 4: Co- } \\
\text { operación en las } \\
\text { esferas jurídica, } \\
\text { científica y tec- } \\
\text { nológica. }\end{array}$ & $\begin{array}{l}\text { (i) No menciona la } \\
\text { precaución sino que } \\
\text { utiliza la palabra "pre- } \\
\text { venir", (ii) el nivel de } \\
\text { riesgo se encuentra } \\
\text { definido como todo } \\
\text { aquello que podría } \\
\text { causar cambios en el } \\
\text { medio físico, (iii) el } \\
\text { daño se concreta bajo } \\
\text { el nombre de "efectos } \\
\text { adversos", (iv) hace } \\
\text { referencia expresa al } \\
\text { elemento científico. }\end{array}$ \\
\hline
\end{tabular}




\begin{tabular}{|c|c|c|c|c|}
\hline $\begin{array}{l}\text { Protocolo de Montreal } \\
\text { relativo a las sustancias } \\
\text { que agotan la capa de } \\
\text { ozono [1987]. } \\
\text { PREÁMBULO: "Decididas } \\
\text { a proteger la capa de ozo- } \\
\text { no adoptando medidas } \\
\text { preventivas para contro- } \\
\text { lar equitativamente el to- } \\
\text { tal de emisiones mundia- } \\
\text { les de las sustancias que } \\
\text { la agotan, con el objetivo } \\
\text { final de eliminarlas, so- } \\
\text { bre la base de los adelan- } \\
\text { tos en los conocimientos } \\
\text { científicos, teniendo en } \\
\text { cuenta aspectos técnicos } \\
\text { y económicos y teniendo } \\
\text { presentes las necesida- } \\
\text { des que en materia de } \\
\text { desarrollo tienen los paí- } \\
\text { ses en desarrollo". }\end{array}$ & $\begin{array}{l}\text { El concepto de riesgo } \\
\text { se reduce a considerar } \\
\text { como tal las sustancias } \\
\text { nocivas que modifican } \\
\text { o pueden modificar la } \\
\text { capa de ozono. }\end{array}$ & $\begin{array}{l}\text { PREÁMBULO: "Reco- } \\
\text { nociendo que la emi- } \\
\text { sión en todo el mundo } \\
\text { de ciertas sustancias } \\
\text { puede agotar consi- } \\
\text { derablemente y modi- } \\
\text { ficar la capa de ozono } \\
\text { en una forma que po- } \\
\text { dría tener repercusio- } \\
\text { nes nocivas sobre la } \\
\text { salud y el medio am- } \\
\text { biente". }\end{array}$ & $\begin{array}{l}\text { P R E Á M B U LO : } \\
\text { "Conscientes de } \\
\text { que las medidas } \\
\text { que se adopten } \\
\text { para proteger la } \\
\text { capa de ozono a } \\
\text { fin de evitar su } \\
\text { agotamiento de- } \\
\text { berían basarse en } \\
\text { los conocimientos } \\
\text { científicos perti- } \\
\text { nentes, teniendo } \\
\text { en cuenta aspec- } \\
\text { tos técnicos y eco- } \\
\text { nómicos". }\end{array}$ & $\begin{array}{l}\text { (i) No menciona al } \\
\text { principio de pre- } \\
\text { caución sino la } \\
\text { adopción de medi- } \\
\text { das preventivas. (ii) } \\
\text { Toma en cuenta as- } \\
\text { pectos económicos } \\
\text { y científicos como } \\
\text { conside raciones } \\
\text { indispensables al } \\
\text { momento de deter- } \\
\text { minar las medidas } \\
\text { pertinentes. (iii) El } \\
\text { concepto de daño se } \\
\text { supedita a la lista de } \\
\text { sustancias conside- } \\
\text { radas en los anexos } \\
\text { del protocolo como } \\
\text { potencialmente da- } \\
\text { ñinas. }\end{array}$ \\
\hline $\begin{array}{l}\text { ARTíCULO 3, NUMERAL 3: } \\
\text { “Las Partes deberían to- } \\
\text { mar medidas de precau- } \\
\text { ción para prever, prevenir } \\
\text { o reducir al mínimo las } \\
\text { causas del cambio climá- } \\
\text { tico y mitigar sus efectos } \\
\text { adversos. Cuando haya } \\
\text { amenaza de daño grave } \\
\text { o irreversible, no debería } \\
\text { utilizarse la falta de total } \\
\text { certidumbre científica }\end{array}$ & $\begin{array}{l}\text { ARTíCULO 3, NUME- } \\
\text { RAL 3: "Cuando haya } \\
\text { amenaza de daño gra- } \\
\text { ve o irreversible". }\end{array}$ & $\begin{array}{l}\text { PREÁMBULO: "pre- } \\
\text { ocupadas porque las } \\
\text { actividades humanas } \\
\text { han ido aumentan- } \\
\text { do sustancialmente } \\
\text { las concentraciones } \\
\text { de gases de efecto } \\
\text { invernadero en la at- } \\
\text { mósfera, y porque ese } \\
\text { aumento intensifica el } \\
\text { efecto invernadero na- } \\
\text { tural, lo cual da como } \\
\text { resultado, en prome- } \\
\text { dio, un calentamiento } \\
\text { adicional de la superfi }\end{array}$ & $\begin{array}{l}\text { ARTíCULO 3, NU- } \\
\text { MERAL 3: “No } \\
\text { debería utilizarse } \\
\text { la falta de total } \\
\text { certidumbre cien- } \\
\text { tífica como razón } \\
\text { para posponer } \\
\text { tales medidas, to- } \\
\text { mando en cuenta } \\
\text { que las políticas } \\
\text { y medidas para } \\
\text { hacer frente al } \\
\text { cambio climático } \\
\text { deberían ser efi- } \\
\text { caces en función } \\
\text { de los costos a fin }\end{array}$ & $\begin{array}{l}\text { (i) Se habla expresa- } \\
\text { mente del concepto } \\
\text { de precaución y no } \\
\text { de prevención. (ii) El } \\
\text { concepto de riesgo es } \\
\text { definido como ame- } \\
\text { naza de daño grave e } \\
\text { irreversible. (iii) Daño } \\
\text { significa aumento de } \\
\text { los gases de efecto } \\
\text { invernadero en la at- } \\
\text { mósfera. (iv) Hace re- } \\
\text { ferencia a que la falta } \\
\text { de certeza científica }\end{array}$ \\
\hline
\end{tabular}




\begin{tabular}{|c|c|c|c|c|}
\hline $\begin{array}{l}\text { como razón para pospo- } \\
\text { ner tales medidas, to- } \\
\text { mando en cuenta que las } \\
\text { políticas y medidas para } \\
\text { hacer frente al cambio } \\
\text { climático deberían ser } \\
\text { eficaces en función de los } \\
\text { costos a fin de asegurar } \\
\text { beneficios mundiales al } \\
\text { menor costo posible...". }\end{array}$ & & $\begin{array}{l}\text { cie y la atmósfera de la } \\
\text { Tierra y puede afectar } \\
\text { adversamente a los } \\
\text { ecosistemas naturales } \\
\text { y a la humanidad". }\end{array}$ & $\begin{array}{l}\text { de asegurar be- } \\
\text { neficios mun- } \\
\text { diales al menor } \\
\text { costo posible". }\end{array}$ & $\begin{array}{l}\text { no puede ser una ra- } \\
\text { zón para posponer la } \\
\text { toma de decisiones } \\
\text { frente al cambio cli- } \\
\text { mático". }\end{array}$ \\
\hline $\begin{array}{l}\text { Protocolo de Cartage- } \\
\text { na sobre bioseguridad } \\
\text { [2000] del Convenio so- } \\
\text { bre la diversidad bioló- } \\
\text { gica. } \\
\text { (I) PREÁMBULO: “Reafir- } \\
\text { mando el enfoque de } \\
\text { precaución que figura en } \\
\text { el principio } 15 \text { de la De- } \\
\text { claración de Río sobre el } \\
\text { Medio Ambiente y el De- } \\
\text { sarrollo". (ii) ARTícULO 1: } \\
\text { “De conformidad con el } \\
\text { enfoque de precaución } \\
\text { que figura en el principio } \\
\text { 15 de la Declaración de } \\
\text { Río sobre el Medio Am- } \\
\text { biente y el Desarrollo...". } \\
\text { (iii) ARTícULO 10, NU- } \\
\text { MERAL 1: "Las decisio- } \\
\text { nes que adopte la Parte } \\
\text { de importación deberán } \\
\text { ajustarse a lo dispuesto } \\
\text { en el artículo } 15 \text { ". }\end{array}$ & $\begin{array}{l}\text { (i) PREÁMBULO: “po- } \\
\text { sibles efectos adver- } \\
\text { sos para la diversidad } \\
\text { biológica, teniendo } \\
\text { también en cuenta los } \\
\text { riesgos para la salud } \\
\text { humana". (ii) ARTí- } \\
\text { CULO 2, NUMERAL 2: } \\
\text { riesgos para la diversi- } \\
\text { dad biológica, tenien- } \\
\text { do también en cuenta } \\
\text { los riesgos para la sa- } \\
\text { lud humana. }\end{array}$ & $\begin{array}{l}\text { ARTÍ́CULO 15: "posi- } \\
\text { bles efectos adversos". }\end{array}$ & $\begin{array}{l}\text { ARTÍCULO 10, } \\
\text { NUMERAL } 6 \text { Y } \\
\text { ARTíCULO 11, } \\
\text { NUMERAL 8: "El } \\
\text { hecho de que no } \\
\text { se tenga certeza } \\
\text { científica por fal- } \\
\text { ta de información } \\
\text { o conocimientos } \\
\text { científicos per- } \\
\text { tinentes sufi- } \\
\text { cientes sobre la } \\
\text { magnitud de los } \\
\text { posibles efectos } \\
\text { adversos de un } \\
\text { organismo vivo } \\
\text { modificado...". }\end{array}$ & $\begin{array}{l}\text { (i) El convenio hace } \\
\text { referencia explícita al } \\
\text { principio de precau- } \\
\text { ción en más de una } \\
\text { oportunidad. (ii) El ar- } \\
\text { tículo } 10 \text { del convenio } \\
\text { contempla la manera } \\
\text { como se aplicará el } \\
\text { principio, en el marco } \\
\text { del mismo. (iii) Hace } \\
\text { referencia a la falta de } \\
\text { certeza científica de la } \\
\text { misma manera que lo } \\
\text { hace el principio } 15 \text {. }\end{array}$ \\
\hline
\end{tabular}




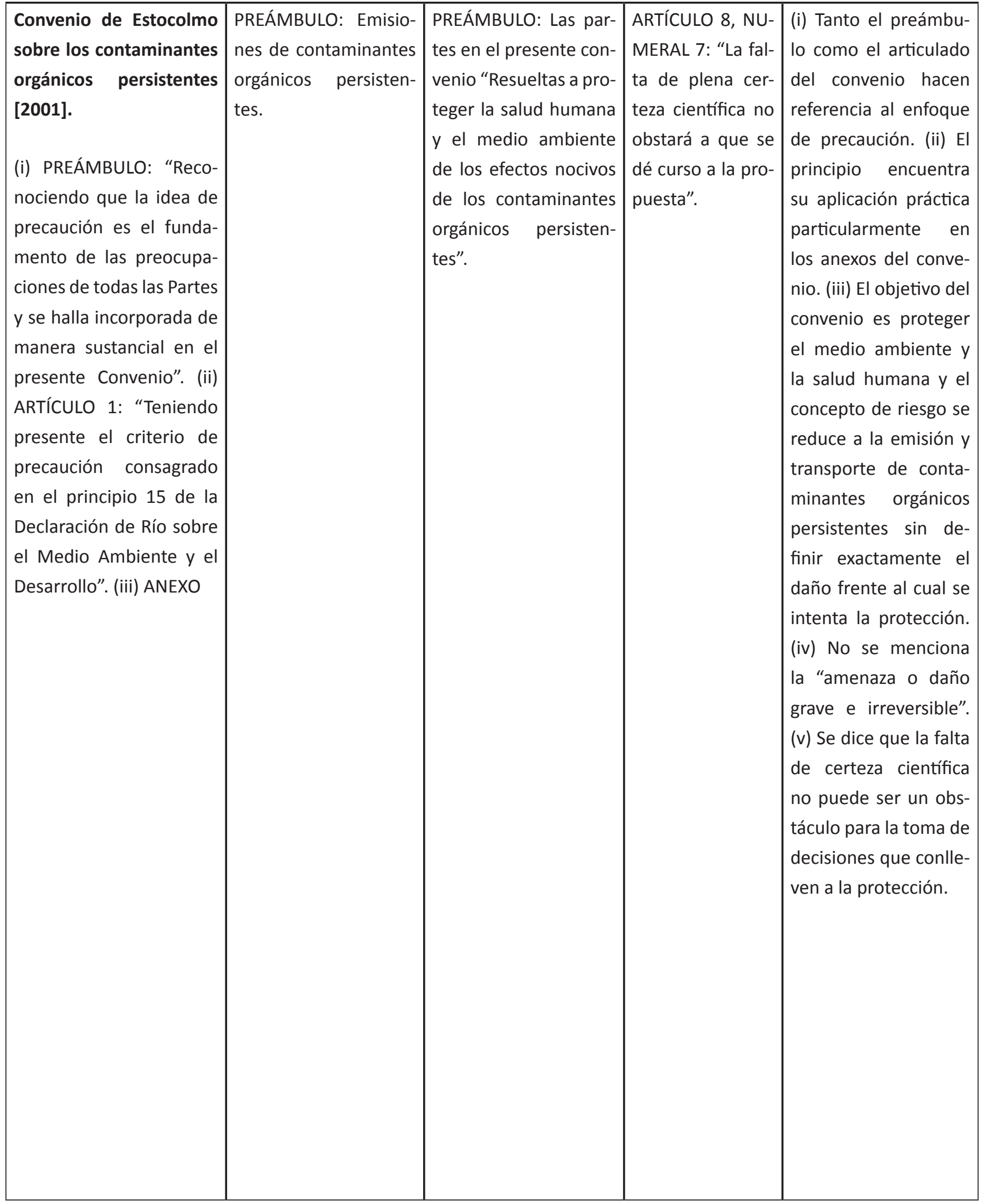


Teniendo en cuenta el cuadro anterior, es posible concluir lo siguiente:

- El riesgo es la característica que define la precaución (Actas de la Mesa Redonda de la Geneva Environment Network, 2002, p. 12). El principio ha sido concebido gracias a una nueva preocupación internacional en torno a un tipo de riesgo que hasta hace poco había mantenido a la comunidad global despreocupada: el riesgo ecológico. Actualmente, diversos instrumentos internacionales regulan de manera diferente la atención que se debe prestar a las posibilidades de ocurrencia de un determinado hecho que constituye el peligro.

- El concepto de riesgo involucra su materialización en un resultado o daño que puede ser considerado más o menos gravoso, transitorio o permanente, según el origen que tenga, dependiendo de la actividad que lo causa y sus consecuencias.

- La incertidumbre científica es la condición sin la cual no se puede aplicar el principio de precaución. Aunque existan razonamientos científicos bajo los cuales sea posible determinar con algún grado de convicción las consecuencias de una actividad, no siempre se evitará la activación de la intervención estatal como consecuencia del mandato incorporado en el principio. El nivel de comprensión de la causación del daño exigido por la norma puede variar, así como también el grado de exposición al riesgo.

En resumen, cada instrumento internacional y su materialización en el ámbito local puede traer consigo diversos niveles de afectación al ambiente, considerados como una exposición al riesgo que son distintos y dan lugar a determinadas consecuencias o daños. Lo anterior, teniendo en cuenta que el principio de precaución no necesariamente exige la intervención de los organismos estatales en todos los casos, y que los niveles de restricción varían según si se tenga algún o ningún grado de certeza científica al respecto.

Además, el lenguaje con el cual se han redactado los mecanismos de derecho internacional es, entonces, el determinador de los niveles de exigencia planteados en ellos. Los contrastes del principio de precaución bajo una circunstancia u otra dependen de la forma utilizada en el preámbulo o los artículos de cada instrumento que contempla su aplicación o lo cita como elemento rector.

Dando aplicación a todo lo mencionado hasta ahora, uno de los aspectos más polémicos del principio de precaución tiene que ver con el grado de discreción interpretativa y de decisión que implica su aplicación por parte de las autoridades estatales locales. Dado que los elementos fundamentales que lo componen (riesgo, daño y falta de certeza científica) pueden variar el nivel de exigencia en la afectación al medio ambiente y los mecanismos para evitarlo, se ha argumentado que este principio podría resultar en una restricción arbitraria al libre comercio.

Pese a que los pronunciamientos de los tribunales internacionales, a los cuales se hizo referencia en párrafos anteriores, han reconocido la importancia de mantener una postura razonablemente preventiva frente a los posibles 
efectos adversos que determinadas actividades puedan generar en el medio ambiente y la salud humana, si algo ha quedado claro es que para ellos, como para algunos países liderados por Estados Unidos, la aplicación del principio no puede resultar en una restricción al intercambio comercial. Entonces, se trata más de un enfoque que ha permitido a la Comunidad Europea, por ejemplo, justificar restricciones comerciales o el incumplimiento de compromisos adoptados por fuera del ámbito del derecho ambiental y en el marco de la Organización Mundial del Comercio (OMc) (Actas de la Mesa Redonda de la Geneva Environment Network, 2002, p. 26).

Desde esta perspectiva, la aplicación del principio de precaución en la conservación de la biodiversidad y dentro del marco de la gestión de recursos ambientales puede tener efectos negativos sobre la economía. Los enfoques más restrictivos del principio, que tienen detrás una interpretación proteccionista, pueden ser utilizados como una manera de disimular los motivos que no necesariamente constituyen una justificación razonablemente aceptada en el contexto comercial. Esto, pues "lamentablemente, la posibilidad de que se produzcan esos abusos ha contribuido sin duda a que el principio de precaución pierda legitimidad en ciertos grupos" (Cooney, 2004).

Aunque en ninguno de los instrumentos internacionales se ha pronunciado aún la última palabra respecto a la pugna entre la protección del medio ambiente ante la falta de certeza científica y la preservación de la libertad de intercambio comercial, es claro que la urgencia de la aplicación del principio de precaución en aquellos ca- sos en los que verdaderamente se desconocen las consecuencias de determinada actividad no ha logrado superar el interés comercial de algunos países. Tal como se verá en la próxima sección, en la mayoría de los escenarios la precaución termina convertida en prevención, pues se condiciona la aplicación de medidas al hecho de que antes las partes interesadas en proteger el ambiente logren demostrar científicamente la existencia del riesgo y la relación entre la actividad potencialmente peligrosa y el daño.

\section{Diferencias entre el principio de precaución y la prevención}

Como se observó en la tabla 1, donde se relacionan algunos de los elementos significativos más importantes de los tratados internacionales en torno al concepto de precaución, es indiscutible la estrecha relación entre este principio y la obligación de prevenir. Tal como se evidencia, es claro que la prevención ha sido tratada como base o sustancia de las normas relativas a la protección del medio ambiente hasta el punto en que se incluye no solamente en los tratados, sino que además se ha discutido en las reuniones de las Conferencias de las Partes, máximo órgano decisorio de los tratados y en las diversas instancias de los más importantes organismos internacionales (Jiménez, 2001, p. 134).

Desde el comienzo de la discusión acerca de la necesidad de preservar el medio ambiente se ha mencionado la importancia de que los Estados tomen medidas para ello en una etapa temprana, frente a las actividades que puedan producir un daño o afectación a través de una actuación determinada. Por lo anterior, la doctrina 
ha entendido que en este escenario se trata del principio más general de todos los consagrados en el ordenamiento internacional ambiental, ya que resulta aplicable casi bajo cualquier situación en la cual se presente un riesgo medioambiental (Uribe, 2010, p.186). Esta consideración puede entenderse si se tiene en cuenta no solo la fragilidad característica de muchos de los ecosistemas del mundo, sino además la dificultad para reparar el daño a ellos ocasionado, situación que dependiendo de cada caso podría tomar largos periodos de tiempo o incluso resultar imposible de remediar.

Por lo anterior, no es de extrañar que la mayoría de los asuntos ambientales internacionales, que van desde la protección de la diversidad hasta el cambio climático, pasando por supuesto por la contaminación marina y las regulaciones relativas a las sustancias consideradas como peligrosas, han mencionado la palabra prevención. Antes de que se considerara siquiera el término precaución, los Estados ya hablaban de la importancia de prevenir desastres ambientales tal como ocurría con los derrames de hidrocarburos en el mar.

La gran diferencia entre uno y otro concepto se encuentra esencialmente en su significado en sentido estricto, y es allí donde reside la importancia del lenguaje. Sin embargo, si se tiene en cuenta el concepto mencionado al comienzo de esta sección, según el cual precaución implica una reacción tendiente a evadir dificultades o daños, mientras que la prevención es una preparación para la evitación de un riesgo, a primera vista no es tan clara la diferencia entre una y otra. De hecho, podrían incluso considerarse como sinónimos. Analizado de este modo, sería posible llegar a entender la utilización indiscriminada de ambos conceptos en los primeros instrumentos internacionales a los que se hizo referencia en la tabla 1 . No obstante, con el paso del tiempo y el aumento en la especificidad de las problemáticas ambientales, así como en los métodos utilizados para descubrirlas y evitarlas, las palabras precaución y prevención han adquirido connotaciones diversas.

Ahora es claro que el elemento diferenciador entre ambos conceptos es la certeza científica. Para prevenir es necesario saber con algún grado de conocimiento cuál es el verdadero peligro que se enfrenta y las consecuencias que este acarrea. Mientras tanto, precaver implica realizar planes frente a lo desconocido: pese a que existen probabilidades $u$ opciones, no se tiene una noción clara de qué es lo que realmente puede llegar a ocurrir. Por un lado, el principio de prevención "se apoya en la certeza científica del riesgo de daño ambiental" (Jiménez, 2001, p. 166) y, por el otro, en el principio de precaución en el que "es consustancial a su propia definición la ausencia de certeza científica absoluta acerca de la probabilidad del riesgo" (Jiménez, 2001, p. 166). Así, en el primero de ellos la evaluación del impacto ambiental es el elemento sin el cual los Estados no pueden tomar decisiones ni actuar ante determinadas actividades. Pese a las múltiples formas que puede adoptar el principio de precaución, en todas y cada una de ellas la motivación para su aplicación es la protección frente a potenciales daños aun cuando "las cadenas causales no son claras y no sabemos que esos daños se concretarán" (Sunstein, 2009, p. 15). 
En resumen, mientras que el principio de prevención exige para su activación un despliegue de consideraciones racionales ciertamente exigentes y comprobables en términos probatorios, el principio de precaución es la interpretación siempre favorable al medio ambiente. A continuación, en la tabla 2 , se sintetizan las diferencias más importantes entre uno y otro concepto.

Tabla 2: Diferencias entre el principio de prevención y el de precaución
Así las cosas, es claro que el concepto que fue materializado en el principio 15 de la Declaración de Río tiene una estrecha relación con el principio de prevención. En términos jurídicos, ambos se complementan perfectamente pues impulsan a los Estados a actuar ante diversos escenarios y con el mismo propósito: la protección del medio ambiente a través de la actuación asertiva y puntual, que permita evitar la ocurrencia de los daños antes de que estos hayan siquiera comenzado a evidenciarse.

\begin{tabular}{|c|l|l|}
\hline Característica & \multicolumn{1}{|c|}{ Prevención } & \multicolumn{1}{|c|}{ Precaución } \\
\hline Temporalidad & $\begin{array}{l}\text { Implica conocer anticipadamente las consecuen- } \\
\text { cias que una determinada actividad puede tener } \\
\text { para el medio ambiente, considerada en una esca- } \\
\text { la de tiempo que corresponde al mediano y largo } \\
\text { plazo. }\end{array}$ & $\begin{array}{l}\text { Se refiere esencialmente a los riesgos esti- } \\
\text { mados en una escala temporal correspondi- } \\
\text { ente a la larga duración. }\end{array}$ \\
\hline Certeza científica & $\begin{array}{l}\text { Su fundamento es el conocimiento anticipado del } \\
\text { daño y de las medidas que podrían adoptarse para } \\
\text { evitarlo. }\end{array}$ & $\begin{array}{l}\text { Se basa en la falta de certeza científica que } \\
\text { otros, dependiendo del mecanismo que lo } \\
\text { consagre, puede ser solamente cuestion- } \\
\text { able. }\end{array}$ \\
\hline Nivel de riesgo & $\begin{array}{l}\text { El peligro al medio ambiente no necesariamente } \\
\text { tiene que ser significativo, basta con que haya } \\
\text { afectación negativa. }\end{array}$ & $\begin{array}{l}\text { En la mayoría de los casos implica que los } \\
\text { riesgos son graves e irreversibles o, por lo } \\
\text { menos, significativos. }\end{array}$ \\
\hline
\end{tabular}

\section{Los límites del principio}

Considerando los matices introducidos por el lenguaje utilizado en cada instrumento en el cual se consagra el principio de precaución, así como el desarrollo interpretativo que ha tenido su aplicación en las diversas instancias internacionales, resulta claro que una palabra puede hacer la diferencia entre el tipo de decisiones que lo acompañan.

En cuanto a la aplicación del principio, se trata entonces de una medida eminentemente polí- tica que se encuentra determinada por el nivel de riesgo que un país considera como aceptable. "Las versiones más precaudatorias y laxas sugieren, muy sensatamente, que una falta de pruebas concluyentes de daño no debería ser motivo para negarse a regular" (Sunstein, 2009, p. 32). De allí que los lineamientos para su uso y la aplicación pueden resultar en una restricción al comercio, en los términos en los que se ha planteado en secciones anteriores, o bien en una interpretación equilibrada. 
Al respecto, la Comisión de Comunidades de la Unión Europea emitió el 2 de febrero de 2000 un comunicado sobre el recurso al principio de precaución, en el cual se mencionan unos parámetros que sintetizan los límites a tener en cuenta por parte de los Estados al momento de aplicarlo. Se trata entonces de (MacNelis, 2000, pp. 547 - 548):

1. La proporcionalidad, que significa que las medidas a tomar tienen que estar en concordancia con el nivel de protección deseado.

2. Que las decisiones no sean discriminatorias. Es decir, que situaciones iguales sean tratadas de la misma manera y hechos disímiles reciban un trato diferenciado, evitando distinciones arbitrarias y argumentos basados en factores ajenos a las actividades mismas, tales como el aspecto geográfico o la sola naturaleza de la acción.

3. Que los países deberán mantener una aproximación consistente en la adopción de las medidas, tratando de asegurarse de que las decisiones tomadas sean comparables en su naturaleza y alcance con otras determinaciones ya adoptadas bajo circunstancias similares.

\section{Que será necesario que los Estados realicen} un análisis de costo- beneficio de lo que dependería tomar medidas de precaución o no hacerlo. Para ello, es importante que se tengan en cuenta las condiciones a corto y largo plazo, así como los intereses económicos y no económicos.

5. Que pese a que el principio de precaución se activa especialmente cuando hay falta de certeza científica, esto no implica que desaparezca la obligación de continuar con las investigaciones para determinar el verdadero riesgo y los potenciales daños. Por el contrario, las medidas de precaución no se pueden extender indefinidamente en el tiempo.

En conclusión, a pesar de que la manera abstracta como se encuentra contemplado el principio de precaución en los diversos instrumentos internacionales puede dar lugar a una interpretación amplia del mismo que lleve a su aplicación arbitraria, también es cierto que existen algunos criterios que gozan de un buen grado de aceptación por parte de la comunidad internacional para combatir, precisamente, esa parcialidad de la que se acusa al principio. Lo anterior, puesto que "cada sociedad y cada persona deben elegir prestar atención a ciertos riesgos. En este sentido la selectividad de las precauciones no es meramente un hecho empírico; es algo conceptualmente inevitable" (Sunstein, 2009, p. 152.

\section{INCORPORACIÓN DEL PRINCIPIO DE PRECAUCIÓN AL DERECHO AMBIENTAL COLOMBIANO}

Han pasado poco más de veinte años desde que las discusiones acerca de la necesidad de un nuevo orden constitucional dieron como resultado la reforma a la Carta Política en 1991. La iniciativa constitucional nació en medio de una "dramática coyuntura en la que el país parecía a la deriva, como sin rumbo" (De la Calle, 2004 , p. 15), por lo que la propuesta de transformación de las instituciones políticas fue bien recibida por todos los estamentos sociales que 
"veían que había oportunidad de cambio constitucional, de renovación de las instituciones y de purificación de las costumbres políticas" (De la Calle, 2004, p. 15). Fue en este contexto en el que, además de todas las vicisitudes internas que promovían el cambio, se hizo visible al interior del país la ya conocida preocupación internacional por el medio ambiente, que venía gestándose desde hace varias décadas en el ámbito global y que por primera vez impactó significativamente a Colombia.

Gracias al desarrollo de las conversaciones previas a la Cumbre de Río, que coincidieron con las de la Convención para el cambio climático y la reforma constitucional a nivel local, Colombia fijó por primera vez su atención en la agenda ambiental de manera seria durante finales de los ochenta y comienzos de los noventa.

Teniendo en cuenta lo anterior, en este capítulo se tratará el tema de la introducción del principio de precaución al sistema jurídico colombiano a través de la Constitución de 1991 y luego se hará un bosquejo general sobre su desarrollo legislativo en los últimos años.

\section{A. La Constitución ecológica de 1991}

El debate actual en torno al tema ambiental, tanto en la esfera internacional como en el ámbito local, es un asunto neurálgico de la agenda política que recoge las interacciones entre el hombre y la naturaleza. Más que el papel instrumental de las normas, que se evidencia a través de la construcción de un camino a la ilustración moral que busca crear conciencia de la necesidad de la conservación, lo verdaderamente importante es que las discusiones ambientales que dan origen a los múltiples artículos en las diversas constituciones del mundo toman a la Tierra, nuestro planeta, como agente protagonista en relación con el hombre. De forma particular, los insumos para la construcción de un nuevo paradigma en cuanto a la visión del mundo natural, que da origen a la Constitución de 1991 en Colombia, vienen del derecho internacional que comenzó a discutir seriamente el concepto de desarrollo sostenible a través ya no solo de la concurrencia e interrelación de lo natural y lo cultural (Worster, 1990), sino además teniendo en cuenta los intereses económicos.

“La finitud de los recursos naturales y el deterioro del medio ambiente estaban conduciendo a una problemática social y económica de imprevisibles consecuencias. Era necesario, entonces, dar respuestas concretas y rápidas, para lo cual se necesitaban instrumentos legales que dieran una imagen de legitimidad a las acciones requeridas" (Macías, 1998, p. 76). Así que no podría haber una mejor oportunidad para colocar la agenda ambiental en el lugar privilegiado que se merecía, que incluirla dentro de los ejes temáticos de la reforma constitucional.

La Corte Constitucional, en su sentencia C-126 de 1998, señaló que la Constitución de 1991 marca un punto a partir del cual se modifica la relación entre el hombre y la naturaleza. En lo que respecta a su rol dentro del ordenamiento jurídico, esta relación es creada y regulada por las normas, pero principalmente por las disposiciones constitucionales. Es por ello que, pese a que no existe en ella ninguna mención expresa al principio de precaución, es indispensable re- 
ferirse la Constitución como el primer paso que dio el país hacia una concepción de precaución en la política ambiental.

El artículo 80 constitucional, que obliga al Estado a planificar el manejo de los recursos naturales y su aprovechamiento de manera tal que garantice el desarrollo sostenible, introduce de forma directa el concepto de prevención en los términos en los que se entendió su significado en el capítulo anterior. En el mismo sentido, el mencionado artículo también advierte sobre la necesidad de controlar los factores de deterioro ambiental, imponer sanciones por las afectaciones que estos causen y velar por la reparación de los daños causados.

Aparece entonces el concepto de desarrollo sostenible como el punto cardinal de referencia que permite analizar la eventual prohibición o regulación de situaciones en materia ambiental, puesto que recoge las obligaciones de las generaciones presentes para con las futuras respecto a la utilización de recursos de manera responsable y preventiva. Esta responsabilidad en cabeza del Estado, de evitar el deterioro ambiental, conservar, restituir o restaurar los recursos naturales, significa que lo ideal es generar riqueza sin perjudicar a las generaciones venideras. Gracias a esta obligación se reconoce de manera indirecta en el ordenamiento jurídico constitucional la validez y aplicación del principio de precaución en el ámbito nacional, haciendo referencia al desarrollo sostenible y al derecho a gozar de un medio ambiente sano, lo cual se traduce, además, en la elevación de este último al rango de derecho fundamental, dada su conexidad con los derechos a la vida y a la salud.
Así las cosas, el problema ambiental en Colombia y en el mundo se comienza a tomar como un factor puramente conservacionista pero también de desarrollo. Todos los artículos sobre el ambiente que se encuentran en la Constitución tienen distinto significado y representan diferentes esferas que se pueden resumir en seis grupos (Macías, 1998, p. 84-88):

\section{El medio ambiente como principio rector del Estado.}

\section{El medio ambiente como derecho colectivo,} social y fundamental. En términos generales, la Constitución de 1991 estableció que la protección o exigencia del cumplimiento de normas ambientales puede hacerse mediante el control judicial a través de figuras como la tutela, la acción popular y la acción de cumplimiento. Así mismo, se encuentra dentro de la Carta Política como uno de los deberes de la persona y del ciudadano quien tiene la obligación de "proteger los recursos culturales y naturales del país y velar por la conservación de un ambiente sano" (Constitución Política de Colombia, Art. 95,8).

\section{El medio ambiente como modelo de desa-} rrollo, que incluye además del artículo 80 los artículos 333 al 334, 339, 340, 361. Al respecto, también se resalta que es deber del Estado encargarse de regular los factores de deterioro ambiental mediante la imposición de sanciones y la exigencia de la reparación del daño ocasionado.

4. El medio ambiente como condicionante de la propiedad privada a través de los artículos 58 , 63 y 66 , en los cuales se introduce la función 
social y ecológica de la propiedad "como límite para el ejercicio de los atributos de la propiedad privada, propiciando la denominada (...) ecologización de la propiedad" (sentencia C-189 del 15 de marzo de 2006). Para el constituyente nacional, la propiedad privada y el crecimiento económico pueden llegar a tener consecuencias negativas en el ambiente o resultados nocivos para el entorno que deben ser considerados en todo momento, pues el interés privado, representado por las actividades económicas, debe estar subordinado al interés general de las generaciones presentes y futuras por la preservación del medio ambiente y el consecuente respeto a la normatividad ambiental en todos sus niveles.

\section{El medio ambiente como componente de} la política internacional, dentro de la cual se encuentra el principio de precaución que nace con el objetivo de precaver los efectos nocivos a la vida humana de algunas actividades cuyos resultados solo se materializan un par de décadas más tarde. En algunos de estos casos es posible que no haya certeza científica absoluta en cuanto al resultado, pese a lo cual la autoridad ambiental tendrá que tomar decisiones tendientes a evitar un peligro de daño grave, de conformidad con "las políticas ambientales trazadas por la ley, en desarrollo de la Constitución, en forma motivada y alejada de toda posibilidad de arbitrariedad o capricho" (sentencia C-189 del 15 de marzo de 2006).

6. El medio ambiente y la estructura organizativa del Estado ya que "todos los aspectos declarativos sobre el tema ambiental requieren instrumentos para ser operativos dentro del funcionamiento y estructura del Estado" (Macías, 1998, p. 86). Artículos como el 267, 268, 289 y otros se refieren a este tema.

Además de todo lo anterior, el principio de precaución ingresa a nuestro ordenamiento jurídico principalmente a través del artículo 226 de la Constitución nacional, en el cual se consagra el mandato de la internacionalización de las relaciones políticas, económicas, sociales y ecológicas. Con ello se incluyen los tratados internacionales en materia ambiental, de los que se habló en detalle en el primer capítulo de este documento.

Aunque no se encuentre taxativamente mencionado en la Constitución de 1991, gracias al tinte ecológico de la misma "el Principio de Precaución, que consiste en que las autoridades ambientales, cuando exista peligro de daño grave e irreversible, la falta de certeza científica absoluta no deberá utilizarse para postergar la adopción de medidas eficaces para impedir la degradación del medio ambiente" (Ley 99 de 1993 , art $1^{\circ}$, num. 6) puede ser considerado como una norma de carácter constitucional y cuya aplicación debe responder a esta naturaleza. Lo anterior se evidencia en sentencias como la C-400 de 1998, la C-012 de 2001 y la C-1189 de 2000, entre otras, en las cuales la Corte Constitucional realiza un análisis de este principio.

En conclusión, la precaución es un elemento importante que permite generar un criterio para la toma de decisiones de la administración y es además una garantía constitucional para la comunidad, que se suma a toda una novedosa 
perspectiva de lo ambiental, y que se puede resumir en los puntos mencionados con anterioridad como transversales a toda la Constitución de 1991. Es por ello que las incipientes autoridades ambientales creadas en Colombia como consecuencia del oportuno momento histórico en el que se desarrolló la Agenda de Río, las negociaciones para la Convención sobre el cambio climático y la nueva Constitución, cuentan con herramientas entre las que se incluyen las normas de rango constitucional que no solo los impulsa a aplicar el in dubio pro ambiente ${ }^{2}$, sino que realmente los vincula de manera directa y obligatoria.

\section{B. El principio de precaución en las principales leyes ambientales}

Ya que fue en aras de implementar verdaderas medidas de control de las actividades potencialmente riesgosas para los ecosistemas que el derecho internacional concretó en el principio de precaución la herramienta fundamental para estimular en los Estados la activación de mecanismos condicionales de estas, el conjunto de normas ambientales que se desarrollarían después en Colombia seguiría esta idea.

Puede considerarse que desde los primeros años del régimen legal ambiental colombiano, el principio de precaución se encuentra previsto "al haber sido incorporado a través de las leyes

2 En múltiple jurisprudencia de la Corte Constitucional, como las sentencias C-339/02 y T-299/08, se ha utilizado esta expresión como sinónimo del principio de precaución y haciendo referencia a que con base en este, siempre que no se tenga certeza científica de una actividad y haya duda sobre si puede ocasionar un daño ambiental o se constituya un peligro, deberá interpretarse a favor del medio ambiente e invirtiendo la carga probatoria. aprobatorias de los tratados suscritos por CoIombia y en la Ley 99 de 1993, del medio ambiente" (García, 2002). Dentro de esta última oración se encuentran dos elementos fundamentales para el desarrollo de esta sección: el primero de ellos es que, pese a que los tratados internacionales tienen fuerza vinculante para los Estados al cumplirse unos requisitos en la esfera internacional, estos convenios deben surtir también un trámite dentro del ámbito nacional, que es el mismo de las leyes ordinarias. El segundo elemento que es importante mencionar es que después de la Constitución de 1991 y de todos los acontecimientos que ocurrieron de manera simultánea en el derecho internacional ambiental, Colombia comenzó una nueva etapa de desarrollo legislativo gracias a un cambio de paradigma en cuanto a las preocupaciones ambientales, que se inauguró con la Constitución pero que se consolidó con la Ley 99 de 1993.

En cuanto al primer elemento se resalta que el nacimiento de los tratados internacionales se caracteriza por tener dos etapas: en la primera de ellas debe entrar en vigor en el ámbito internacional y, en la segunda, en la esfera local de cada Estado Parte.

En esa primera etapa (Nieto, 2012 y UNEP, s. f.), el Consejo de Administración del PNUMA ${ }^{3}$ identifica un problema ambiental de impacto global y convoca a un Comité Intergubernamental de

3 El PNUMA es el organismo principal de las Naciones Unidas en lo relativo al medio ambiente. Es el encargado de identificar las cuestiones que necesitan de la cooperación internacional y de integrar los temas ambientales a la agenda global del sistema de Naciones Unidas, entre otros. El principal órgano rector y legislativo del PNUMA es el Consejo de Administración compuesto por 58 miembros elegidos por la Asamblea General de Naciones Unidas. 
Negociación ${ }^{4}$ (UNEP, s. f. p. 11) que comienza a discutir el texto del tratado que intentará dar solución a la problemática. Una vez los negociadores del Comité se ponen de acuerdo, adoptan el texto que no es vinculante aún para los países, pues esta adopción solamente implica la aceptación de que ese texto fue el que efectivamente se negoció. Posteriormente, los países conocen el texto, hacen una lectura superficial de él y pueden firmarlo o no; si lo hacen, con ello solo se entiende que se comprometen a no ir en contra del tratado. El último paso es la ratificación, que ocurre luego de que los gobiernos y las entidades encargadas de manejar internamente los temas que comprende el convenio han dado su concepto favorable. Con esto, y una vez que nazca a la vida jurídica internacional en los términos pactados en él ${ }^{5}$, se entiende que el tratado tiene fuerza vinculante para los países parte.

Superada esta etapa comienza el proceso para hacer que el tratado entre en vigor en la vida jurídica nacional. La Cancillería elabora y radica en el Congreso un proyecto de ley que debe ir firmado por todos o por algunos de los ministros de las carteras que tengan alguna relación con el tema del convenio (según criterio de la Canci-

4 El establecimiento de esta estructura marca el comienzo de todo el proceso de negociación del futuro tratado o convenio.

5 Los tratados establecen dentro de sus provisiones la manera como nacerán a la vida jurídica internacional. Usualmente, al final del documento se incluye una cláusula que puede estar redactada más o menos así: "El presente Convenio entrará en vigor el (por ejemplo: nonagésimo) día después de la fecha en que haya sido depositado el (por ejemplo: vigésimo, trigésimo) instrumento de ratificación, aceptación, aprobación o adhesión", y una fórmula similar se utiliza para los protocolos. En cuanto a los países que ratifican, aceptan, aprueban o se adhieren al tratado o a sus protocolos con posterioridad a su nacimiento a la vida jurídica internacional, comúnmente se estipula que el Convenio entrará en vigor para esa parte el (por ejemplo: vigésimo, trigésimo) día después de que haya depositado su instrumento de ratificación, aceptación, aprobación o adhesión.
Ilería), y cuyo texto debe ser idéntico al ratificado por el país en el ámbito internacional. Una vez surte el trámite de cualquier ley ordinaria y es aprobado por el Congreso, la ley que contiene el tratado pasa a sanción presidencial y debe superar el control de constitucionalidad que hace la Corte Constitucional en el ejercicio de sus funciones. Por último, la misma Cancillería prepara y deposita el instrumento de ratificación ante quien corresponda, según lo estipulado en el tratado. Algunos días después de esto entrará en vigor para el país si ya lo ha hecho en el contexto internacional.

Todo el proceso anterior es precisamente el que surtieron, por ejemplo, la Convención marco de las Naciones Unidas sobre el cambio climático cuando ingresó a nuestro país proveniente del derecho internacional, gracias a su consagración en el artículo 3, numeral 3 de la Ley 164 de 1994. Con esto queda expuesto el trámite para traer a la vida nacional normas de carácter internacional: aprobación en el Congreso, ratificación presidencial y posterior control de constitucionalidad realizado por la Corte.

Por otro lado, la nueva etapa de desarrollo normativo que se da en Colombia como consecuencia de la movilización internacional hacia el tema ambiental y la constitucionalización de las preocupaciones ecológicas, trae consigo todo un bloque de regulaciones que complementan y amplían el espectro ya creado por el derecho positivo. Dentro de esas normas anteriores a 1991 se encontraban, por ejemplo, el Decreto 2811 de 1974 o Código de Recursos Naturales que aunque subrogado y derogado parcialmente por su heredera la Ley 99 de 1993, en sus artículos 
39 literal G y 193 introduce tácitamente algunas características del principio de precaución, a través del llamado a mantener una actitud de precaución en la construcción de las instalaciones para la explotación de hidrocarburos y gas natural, así como en la de carreteras y vías férreas. Pese a su antigüedad, esta norma aún se encuentra en su mayoría vigente, funciona como el principal referente en esta materia y a lo largo de los años ha sido reglamentada a través de decretos en un sinnúmero de oportunidades.

\section{La Ley 99 de 1993 y un nuevo paradigma ambiental}

El régimen ambiental inaugurado con la mencionada Ley 99 de 1993 se ha ido expandiendo a lo largo de los años a través de un sistema complejo de otras leyes y decretos. Actualmente, este se encuentra compuesto, además, por varios bloques de disposiciones relativas al régimen sancionatorio, al licenciamiento y a la conservación de los recursos naturales como el agua, el aire y el aprovechamiento forestal.

En primer lugar, es indispensable señalar que la Ley 99 "por la cual se crea el Ministerio del Medio Ambiente, se reordena el Sector Público encargado de la gestión y conservación del medio ambiente y los recursos naturales renovables, se organiza el Sistema Nacional Ambiental, sINA, y se dictan otras disposiciones", considera el principio de precaución de manera directa en su primer artículo. En el numeral sexto, donde se enuncian los principios generales como fundamentos de la política ambiental colombiana, menciona que:
La formulación de las políticas ambientales tendrá en cuenta el resultado del proceso de investigación científica. No obstante, las autoridades ambientales y los particulares darán aplicación al principio de precaución conforme al cual, cuando exista peligro de daño grave e irreversible, la falta de certeza científica absoluta no deberá utilizarse como razón para postergar la adopción de medidas eficaces para impedir la degradación del medio ambiente.

Allí, la Ley introduce la investigación científica como uno de los elementos del principio, y por la redacción del artículo se podría concluir que le otorga el rol más importante en la definición de precaución. No obstante, la segunda frase del articulado se limita a copiar el principio 15 de la Declaración de Río, en los mismos y exactos términos en los que allí está redactado.

La precaución aparece en la Ley 99 de 1993 en una segunda oportunidad, cuando el artículo 5 que establece las funciones del Ministerio del Medio Ambiente resalta, en su numeral 25, el establecimiento de unos límites máximos de emisión, transporte, depósito y descarga de sustancias que pueden ser nocivas para el ambiente, con base en estudios técnicos. Esto, por cuanto la misma norma aclara que estos límites serán trazados sin perjuicio de la aplicación del principio de precaución.

La constitucionalidad del artículo 1.6 fue demandada y decidida varios años después de la expedición de la Ley 99 de 1993, mediante la sentencia de constitucionalidad número 293 del 23 de abril de 2002 (C-293/02), cuyo magistrado ponente fue el doctor Alfredo Beltrán Sierra. La Corte utilizó esta oportunidad para 
referirse también al artículo 5.25 mencionado en el párrafo anterior, a propósito de esta demanda en la que el accionante argumentó que la redacción del principio de precaución carecía de unidad de criterio porque introducía "dos conceptos constitucionales y legales contrarios y antagónicos" (sentencia C-293 del 23 de abril de 2002). Según esto, existe una contradicción entre la preponderancia que se le da a la investigación científica como base de la formulación de las políticas ambientales y la "carta en blanco" que el artículo entrega a la autoridad ambiental para que adopte decisiones sin tener fundamentos positivos para hacerlo.

Por su parte, la Corte Constitucional resuelve en la mencionada sentencia, que "cuando la autoridad ambiental debe tomar decisiones específicas, encaminadas a evitar un peligro de daño grave, sin contar con la certeza científica absoluta, lo debe hacer de acuerdo con las políticas ambientales trazadas por la ley, en desarrollo de la Constitución, en forma motivada y alejada de toda posibilidad de arbitrariedad o capricho". Con ello se desecha la hipótesis del accionante según la cual los Actos Administrativos podrían estar revertidos de arbitrariedad y contradice el hecho de que estos pueden, además, ser demandados ante la jurisdicción ordinaria.

\section{Régimen sancionatorio}

Uno de los grandes bloques de regulación en materia ambiental, que se desprende de las facultades otorgadas a las autoridades por la Constitución y consagrados positivamente en el artículo 5 de la Ley 99 de 1993, es el de la Ley 1333 de 2009 “Por la cual se establece el procedimiento sancionatorio ambiental y se dictan otras disposiciones". Aunque en esta norma, como en la Constitución, tampoco aparece mencionada expresamente la palabra "precaución", como sí ocurre con "prevención", indirectamente se relaciona con el objeto del principio 15 que fuere consagrado en el artículo 1.6 de la Ley 99 de 1996 y que intenta la protección del ambiente aún frente a la carencia de bases científicas.

El artículo primero de la mencionada ley es importante porque indica la titularidad de la potestad sancionatoria en materia ambiental y, al igual que como ocurre cuando se aplica el principio de precaución ante una determinada actividad cuyas consecuencias nocivas para el ambiente no han podido ser determinadas científicamente por la autoridad, invierte la carga de la prueba y la deposita en cabeza del infractor. Por lo anterior, no es de extrañar que la constitucionalidad de esta disposición haya sido demandada en repetidas oportunidades (sentencias C-595 del 27 de julio de 2010, C-596 del 27 de julio de 2010, C-742 del 15 de septiembre del 2010, C-1007 del 6 de diciembre de 2010). Sin embargo, en todos estos fallos la inversión de la carga de prueba se ha mantenido y la Corte Constitucional la ha defendido con fundamento en que esta regulación no desconoce el principio de presunción de inocencia, pues resulta conforme a la Constitución al ser razonable, perseguir un fin valioso, ser además útil, necesaria y proporcionada para conseguir la protección del medio ambiente.

Teniendo en cuenta lo esbozado en el capítulo primero de este escrito, la prevención y la 
precaución son similares en el sentido en que establecen todas las actuaciones tendientes a prepararse o disponerse anticipadamente para evitar un riesgo. La gran diferencia entre ambas se encuentra en que se entiende que la autoridad ambiental actúa motivada por la primera cuando hay elementos materiales y científicos que permitan concluir la existencia del peligro o el daño con relativa certeza, mientras que la segunda se activa ante la inexistencia de dicha certeza científica. Considerando lo anterior, es consecuente concluir que la Ley 1333 de 2009 introduce ambos conceptos cuando en los artículos 4, 12 y 13 habla de las funciones de la sanción ambiental, el objeto de las medidas preventivas y el procedimiento para aplicarlas.

\section{Licenciamiento ambiental}

El Decreto 2820 de 2010 es la norma que reglamenta el título VIII de la Ley 99 de 1993, y en ella se encuentra todo lo relacionado con el licenciamiento ambiental. Este es el último de múltiples decretos que han sido expedidos con el paso del tiempo y que tratan esta materia.

Al igual que en el régimen sancionatorio, aquí tampoco hay ninguna mención directa al principio de precaución. Sin embargo, también puede considerarse que las referencias a la prevención aplican igualmente en casos de falta de certeza científica, gracias a su consagración en los artículos 1 y 5.25 de la Ley 99 de 1993. Teniendo en cuenta lo anterior, las menciones a la prevención en el régimen de licencias ambientales se pueden resumir de la siguiente manera:
- En las definiciones del artículo 1 en las que se habla de las acciones preventivas como aquellas encaminadas "a evitar los impactos y efectos negativos que pueda generar un proyecto, obra o actividad sobre el medio ambiente". También se refiere al Plan de Manejo Ambiental que incluye las medidas encaminadas a la protección del medio ambiente.

- El concepto mismo de la licencia ambiental, contemplado en el artículo tercero, incluye los elementos del principio, tanto en el sujeto como en el objeto: el desarrollo de todas las actividades que puedan representar un peligro o daño para el ambiente se encuentran condicionados a la obtención de una licencia ambiental cuyo objetivo esencial es precisamente la protección de la biosfera.

- En el parágrafo 5 del artículo 8 cuando otorga competencias preventivas al Ministerio de Ambiente para tomar medidas e imponer sanciones frente a la introducción de especies foráneas al país.

- En el literal b) del numeral 3 del artículo 35 cuando al indicar los requisitos para la integración de las licencias ambientales menciona el tipo de medidas que debe incluir el nuevo Plan de Manejo Ambiental Integrado.

- En el numeral 7 del artículo 39 que trata las acciones que deberá tomar la autoridad ambiental para ejercer control y realizar seguimiento de todas las actividades y proyectos dentro de sus competencias.

En resumen, tal como se reconoció, el régimen de licencias ambientales no habla de precau- 
ción pero sí de prevención. En todo caso, siempre lo hace de manera similar al mencionar en los distintos artículos las medidas de prevención, mitigación, corrección y compensación de los impactos ambientales. Sin embargo, nunca se hace referencia a la certeza científica o al nivel del daño o peligro requerido para activar la reacción de la autoridad ambiental en cabeza, tanto del Ministerio como de las Corporaciones Autónomas Regionales.

A propósito de lo anterior, vale la pena resaltar lo mencionado en capítulos anteriores respecto a la no inclusión del análisis de los Actos Administrativos del Ministerio y de las Corporaciones en este escrito. De la misma manera, aunque el Decreto 2820 de 2010 no incluye expresamente criterios para delimitar y aplicar el principio, cada entidad tendrá consideraciones disímiles -unas quizá más estrictas que otras-, pero siempre se aplicarán según las particularidades de los casos concretos.

Por último, es indispensable señalar que la introducción del concepto de precaución en las principales leyes ambientales colombianas ocurre de manera directa y casi exclusiva en la Ley 99 de 1993. De allí en adelante, las demás disposiciones analizadas únicamente hablan de prevención en el sentido amplio del término, lo que significa que aunque hacen referencia a la necesidad de bases técnicas o científicas para la toma de decisiones, en muchas oportunidades no se trata este elemento de manera clara. De lo cual se podría entender que para el caso de las leyes ambientales referentes al régimen sancionatorio y al licenciamiento ambiental, prevención y precaución son sinónimas.
Todo lo anterior se refuerza si al examinar otras leyes, como por ejemplo la 472 de 1998 que desarrolla el artículo 88 de la Constitución referente a las acciones populares y de grupo. Alí se encuentra que algunos de estos mecanismos jurídicos, creados especialmente para la defensa de los derechos colectivos, tienen carácter preferente cuando intentan prevenir un daño o peligro (Ley 472 de 1998, arts. 5 y 6) y que mediante el artículo 5 de la misma Ley se presentan las medidas cautelares que se pueden adoptar en cualquier momento del proceso y que pretenden alcanzar ese fin de preservar el medio ambiente como un derecho colectivo.

\section{DE LA TEORÍA A LA PRÁCTICA: JURISPRUDENCIA SOBRE EL USO DEL PRINCIPIO DE PRECAUCIÓN EN COLOMBIA}

Una vez analizados los orígenes del principio de precaución en el ámbito internacional, y su introducción en nuestro sistema jurídico a través de la Constitución Política de 1991 y las leyes ambientales creadas después, es importante analizar ahora la forma como la jurisprudencia de las altas Cortes lo han aplicado en los diferentes temas posibles. Para ello se realizará una pequeña muestra de compilación jurisprudencial, en la que se agruparán algunas sentencias que tratan el derecho al medio ambiente sano en relación con otros temas como utilización del agua, residuos, diversidad biológica, entre otros.

Nótese que no se utiliza el término "línea jurisprudencial”, pues lo importante no será el problema jurídico que cada providencia intenta re- 
solver, sino la manera de hacerlo mediante la apelación al principio de precaución. Se tendrán los mecanismos jurisdiccionales que tienen los ciudadanos para reclamar el derecho al medio ambiente sano como derecho colectivo o como derecho fundamental en conexidad con la salud y la vida digna.

Así las cosas, en este capítulo se analizarán las determinaciones adoptadas por la Corte Constitucional a través de las decisiones de tutela, y del Consejo de Estado mediante la revisión de las acciones populares que han aplicado el principio en los diferentes temas posibles. Después de esto y teniendo en cuenta esa compilación jurisprudencial, se introducirán algunas conclusiones preliminares.

Antes de presentar el cuadro con la información de todo lo mencionado, es indispensable señalar la metodología y los criterios utilizados para seleccionar las sentencias que aparecerán a continuación de algunas anotaciones.

Se considera importante hacer una diferenciación entre el tipo de acción y la Corporación que la decide, puesto que la finalidad de salvaguardar el derecho al medio ambiente sano se puede alcanzar a través del ejercicio de diversos mecanismos. Además de los medios ordinarios como la utilización de la vía gubernativa y las acciones de nulidad y restablecimiento del derecho, que se pueden activar cuando se trata de actos administrativos que ponen en peligro el bien jurídico protegido o de actuaciones de una autoridad pública que acarrean igual o similares consecuencias, el ordenamiento contempla otras acciones especializadas en la defensa de los intereses colectivos. En la esfera del derecho administrativo se trata de las acciones populares, mientras que constitucionalmente se cuenta con la tutela cuando el medio ambiente sano se encuentra vulnerado pero en conexidad también se perturba otro derecho, esta vez uno de carácter fundamental. Por tratarse de mecanismos especiales, todas las sentencias analizadas se refieren a estas dos clases de acciones.

Sin ser el objetivo de este escrito entrar en mucho detalle acerca del procedimiento, las características o los requisitos de las acciones populares y de tutela, sí es válido realizar al menos una breve referencia. Las primeras se encuentran reguladas por la Ley 472 de 1998, mientras que la última se rige por el Decreto Ley 2591 de 1991. El artículo 88 de la Constitución nacional menciona que se utilizan las acciones populares "para la protección de los derechos e intereses colectivos, relacionados con el patrimonio, el espacio, la seguridad y la salubridad públicos, la moral administrativa, el ambiente, la libre competencia económica y otros de similar naturaleza". Con ello, la acción popular se presenta como institución utilizada, por ejemplo, para la protección del medio ambiente con múltiples funciones tales como evitar el daño contingente, hacer cesar el peligro, la amenaza, la vulneración o agravio sobre los derechos e intereses colectivos, o restituir las cosas a su Estado anterior cuando fuere posible (Carreño, 2010).

El artículo 4 de la Ley 472 de 1998, en su literal c) menciona que son derechos e intereses colectivos relativos al ambiente: 
La existencia del equilibrio ecológico y el manejo y aprovechamiento racional de los recursos naturales para garantizar su desarroIlo sostenible, su conservación, restauración o sustitución. La conservación de las especies animales y vegetales, la protección de áreas de especial importancia ecológica, de los ecosistemas situados en las zonas fronterizas, así como los demás intereses de la comunidad relacionados con la preservación y restauración del medio ambiente.

Adicional a lo anterior, el literal a) del mismo artículo incluye el derecho a gozar de un medio ambiente sano.

Pese a que el derecho al medio ambiente sano forma parte importante de la Constitución, en ningún lugar de ella se habla de este como un derecho fundamental susceptible de ser amparado por vía de tutela. Entonces, aunque su protección es una obligación de carácter constitucional, no por ello se puede concluir inmediatamente que su puesta en peligro o la causación de daños signifiquen la procedencia de una acción de tutela como mecanismo de protección. Nuestra Corte Constitucional en sentencias como la T-415 del 17 de junio de 1992, así como en la copiosa jurisprudencia que le sigue, ha aceptado "proteger el derecho al medio ambiente sano, no obstante su carácter de colectivo, siempre y cuando por conexidad se esté afectando uno de los llamados derechos fundamentales de aplicación inmediata" (Amaya, 2010, p. 164).

Así las cosas, el primer requisito que se debe cumplir en cualquier situación en la cual se pretenda incoar una acción de tutela para proteger el derecho al medio ambiente sano es que se encuentre en una situación fáctica que permita evidenciar una conexión entre este y otros derechos fundamentales como la salud o la vida digna. Adicionalmente, la misma jurisprudencia de la Corte Constitucional ha establecido como requisitos para la procedencia de la tutela la existencia de no cualquier clase de perjuicio, sino uno que sea grave o irremediable, inminente o inmediato. Esto por cuanto la tutela fue concebida como una acción judicial subsidiaria, residual y autónoma, dirigida a permitir el control constitucional de las acciones u omisiones de las autoridades públicas y, excepcionalmente, de los particulares. Su precedencia está limitada entonces a que el afectado no disponga de otros mecanismos de defensa judicial o de ningún recurso contra el caso en examen, salvo cuando se trate de mecanismo transitorio para evitar un perjuicio irremediable.

Pero volviendo a las consideraciones previas a la presentación de la breve compilación jurisprudencial, se aclara ahora que el orden en el que aparecen ubicadas las providencias se encuentra determinado por la cronología, es decir, de la más antigua a la más nueva. Esto permitirá comprender cómo ha cambiado o se ha mantenido la definición del principio de precaución y su aplicación, así como cuáles han sido algunos de los temas más recurrentes en los que se ha apelado a él.

Por otra parte, la búsqueda de las sentencias se realizó a través de la base de datos digital de Lex Base; para ello se utilizaron las palabras "principio de precaución" y "precaución" como motores de búsqueda. Naturalmente, cada resultado 
debió ser analizado antes de decidir si se incluiría o no, puesto que no todas las providencias que aparecieron tenían estrecha relación con el tema de estudio o hacían algún aporte.

Además de lo mencionado anteriormente, otro criterio tenido en cuenta al momento de incluir estas decisiones judiciales dentro de la compilación, fue la lectura de los hechos planteados en cada caso particular, pues en muchos de ellos se mencionaba el principio de precaución pero haciendo referencia a acontecimientos completamente ajenos al derecho ambiental y que no se relacionaban con este ni siquiera de manera indirecta. Múltiples sentencias que aparecieron trataban, por ejemplo, sobre la semaforización de una vía o su mala señalización, contenido este que nada tiene que ver con el objeto de estudio trazado en este escrito.

Tampoco se incluyeron fallos en los que el demandante apelaba al principio de precaución pero la Corte Constitucional o el Consejo de Es- tado no emitían ningún pronunciamiento al respecto. La razón de esta consideración es senciIla si se reconoce que de lo que se trata es de identificar cómo la jurisprudencia de las altas Cortes lo ha aplicado en los diferentes temas posibles y no cómo las personas lo han invocado en sus acciones.

Finalmente, todas las providencias del Consejo de Estado analizadas son emitidas por la Sección Primera de la Sala de lo Contencioso Administrativo, de conformidad con el Acuerdo 55 del 2003 por medio del cual se modifica el reglamento de esta Corporación. En este se establece que corresponde a la Sección Primera conocer "las acciones populares con excepción de las que se atribuyan a la sección tercera"; esta a su vez conoce de las que versan sobre asuntos contractuales y con el derecho a la moralidad administrativa. Así las cosas, todas las acciones relacionadas con la protección de los derechos colectivos como el medio ambiente sano son competencia de la Sección Primera. 
Tabla 3: Jurisprudencia sobre el principio de precaución

\begin{tabular}{|c|c|c|c|}
\hline & Fallo & Tema y hechos & $\begin{array}{l}\text { El principio de precaución en las consideracio- } \\
\qquad \text { nes de la Corte }\end{array}$ \\
\hline 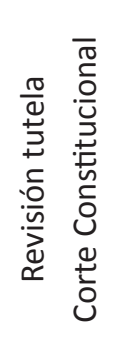 & 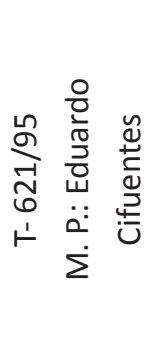 & $\begin{array}{l}\text { AGUA: (i) Empresa maderera construye en } 1973 \\
\text { un canal para comunicar un río y una quebrada } \\
\text { sin permiso ambiental. (ii) El río invade otros } \\
\text { caudales y afecta un complejo sistema hídrico. } \\
\text { (iii) El Inderena ordena a la empresa realizar di- } \\
\text { versas obras pero el problema persiste. (iv) Cor- } \\
\text { ponariño culpa a otras entidades. }\end{array}$ & $\begin{array}{l}\text { Corponariño, como autoridad ambiental encar- } \\
\text { gada de coordinar el desarrollo ambiental de su } \\
\text { jurisdicción, no puede eludir su responsabilidad } \\
\text { trasladándola a otras entidades. La Corte con- } \\
\text { sidera que esta actitud desconoce los principios } \\
\text { de precaución y de prevención consagrados en } \\
\text { la Ley } 99 \text { de } 1993 \text {. }\end{array}$ \\
\hline 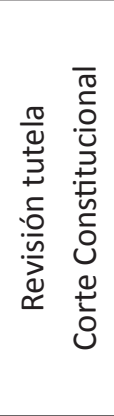 & 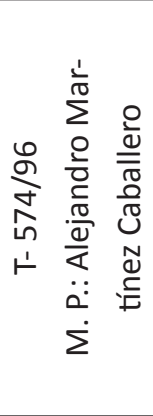 & $\begin{array}{l}\text { PETRÓLEO/AGUA: (i) El } 26 \text { de febrero de } 1996 \\
\text { hubo un derrame de petróleo mientras se re- } \\
\text { alizaba una operación de tanqueo de un buque } \\
\text { en el puerto de Tumaco. (ii) Ecopetrol activó } \\
\text { el plan nacional de contingencia para los der- } \\
\text { rames mayores. (iii) Diversas autoridades téc- } \\
\text { nicas y ambientales encontraron graves afecta- } \\
\text { ciones al ecosistema marítimo y de manglar. }\end{array}$ & $\begin{array}{l}\text { La precaución es una función del Minambi- } \\
\text { ente, esencial para la valoración de los costos } \\
\text { económicos del deterioro ambiental y la con- } \\
\text { servación del ambiente (artículo 5, Ley 99/93). } \\
\text { El principio debe ser utilizado para enfrentar } \\
\text { daños potenciales que tengan incertidumbre, } \\
\text { sin importar que sean causados por el gobierno } \\
\text { o por particulares. }\end{array}$ \\
\hline 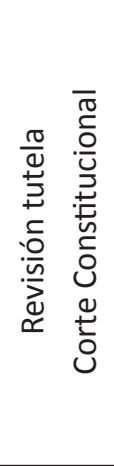 & 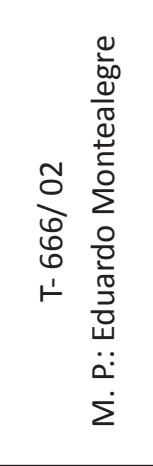 & $\begin{array}{l}\text { AGUA: (i) En cumplimiento de una orden del } \\
\text { Consejo de Bogotá, el } 23 \text { de febrero de } 1993 \\
\text { el Acueducto de la ciudad delimitó las rondas } \\
\text { de los cuerpos de agua del Distrito. (ii) También } \\
\text { se definieron algunas zonas de uso público y } \\
\text { de preservación. (iii) Una vecina de estas áreas } \\
\text { delimitadas interpone tutela por considerar } \\
\text { violados sus derechos a la propiedad, debido } \\
\text { proceso, etc. }\end{array}$ & $\begin{array}{l}\text { La Corte cita la Declaración de Estambul, adop- } \\
\text { tada en el marco del Programa de las Naciones } \\
\text { Unidas sobre Asentamientos Humanos, recono- } \\
\text { ciendo que se deben tomar medidas compat- } \\
\text { ibles con el principio de precaución, "que se } \\
\text { aplicará de manera generalizada según las ca- } \\
\text { pacidades de los países" justificando la delimit- } \\
\text { ación de las rondas de los cuerpos de agua. }\end{array}$ \\
\hline 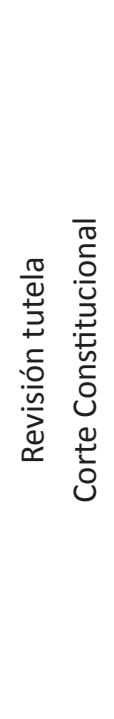 & 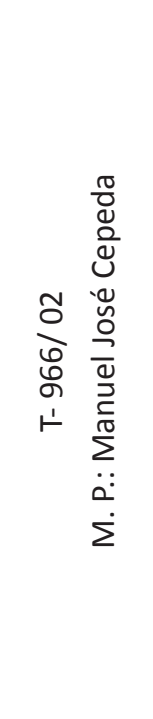 & $\begin{array}{l}\text { SALUD/AIRE: (i) Un molino de arroz realizaba } \\
\text { quemas de la cascarilla del arroz para conver- } \\
\text { tirlo en abono. (ii) El accionante vive cerca del } \\
\text { lugar de las quemas y dice haber visto afectada } \\
\text { su salud, especialmente en su sistema respi- } \\
\text { ratorio. (iii) La sociedad accionada responde } \\
\text { que no puede concluirse con absoluta certeza } \\
\text { que la afección respiratoria del accionante sea } \\
\text { causada por la quema de la cascarilla, hipótesis } \\
\text { que fue corroborada por Medicina Legal. (iv) } \\
\text { Informes de calidad del aire en el sector indica- } \\
\text { ban que se trataba de uno altamente contami- } \\
\text { nado y por encima de los límites permitidos. }\end{array}$ & $\begin{array}{l}\text { Debe existir un nexo de causalidad entre la que- } \\
\text { ma de la cascarilla y la afectación a la salud, y } \\
\text { el impacto tiene que ser resultado exclusivo de } \\
\text { la actividad de la sociedad accionada. Aunque } \\
\text { bastaría con tener solo indicios para que se } \\
\text { aplicara el principio de precaución, habría que } \\
\text { determinar el remedio para el impacto ambien- } \\
\text { tal y para la salud del actor, así como el alcance } \\
\text { de dicho impacto: si es económico a través del } \\
\text { pago de una indemnización; sancionatorio me- } \\
\text { diante la prohibición del desarrollo de la activi- } \\
\text { dad, si es general o particular. Para la Corte esto } \\
\text { requiere de elementos que son propios de la } \\
\text { acción popular y no de la tutela. }\end{array}$ \\
\hline
\end{tabular}




\begin{tabular}{|c|c|c|c|c|}
\hline 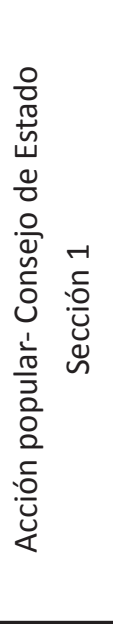 & 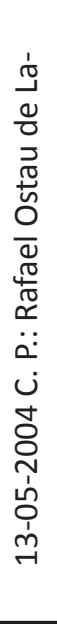 & 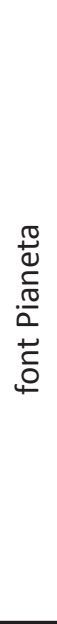 & $\begin{array}{l}\text { AGUA: (i) El abastecimiento de agua de Bogo- } \\
\text { tá depende } 70 \% \text { del sistema Chingaza. (ii) En } \\
\text { diciembre de 1996, la CAR desafectó un área } \\
\text { de esta reserva forestal por solicitud de la Em- } \\
\text { presa de Acueducto de Bogotá con la condición } \\
\text { de que el } 80 \% \text { de esa área se destinara a la con- } \\
\text { servación de la vegetación nativa. (iv) Se trami- } \\
\text { taron } 500 \text { solicitudes de licencia ambiental para } \\
\text { vivienda en el área desafectada. }\end{array}$ & $\begin{array}{l}\text { Pese a que el actor "no probó los elementos de } \\
\text { la responsabilidad de los daños de los derechos } \\
\text { colectivos", el Consejo de Estado aplica el prin- } \\
\text { cipio de precaución con fundamento en que el } \\
\text { desarrollo de urbanizaciones en la zona exclu- } \\
\text { ida de la reserva forestal implica intervención } \\
\text { humana en el área. Se tiene en cuenta además } \\
\text { "que el principio pro natura exige privilegiar el } \\
\text { mantenimiento y la preservación de los eco- } \\
\text { sistemas y los entornos naturales frente a la } \\
\text { exigibilidad de ciertos derechos de explotación } \\
\text { económica que el propietario dice ostentar". }\end{array}$ \\
\hline 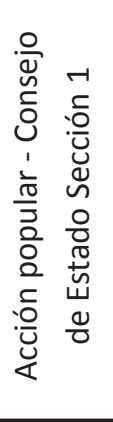 & 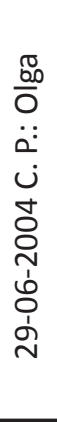 & 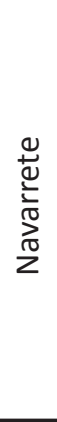 & $\begin{array}{l}\text { MANEJO DE RESIDUOS: (i) Minambiente au- } \\
\text { toriza el almacenamiento de materiales tóxicos } \\
\text { que luego serían incinerados en el centro de la } \\
\text { ciudad de Tunja. (ii) En la demanda se solicitan } \\
\text { como medidas cautelares la realización de un } \\
\text { estudio técnico por parte del Minambiente y } \\
\text { que el alcalde de Tunja impida la entrada de } \\
\text { los residuos. (iii) El Tribunal Administrativo de } \\
\text { Boyacá niega las medidas y en su lugar vincula } \\
\text { a otras entidades. }\end{array}$ & $\begin{array}{l}\text { La solicitud de las medidas cautelares respon- } \\
\text { de al principio de precaución ambiental, que } \\
\text { en todo caso se valora de conformidad con el } \\
\text { material probatorio en el fallo y "para evitar la } \\
\text { posibilidad de un daño permanente en el medio } \\
\text { ambiente". }\end{array}$ \\
\hline 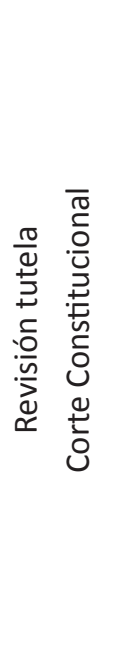 & & 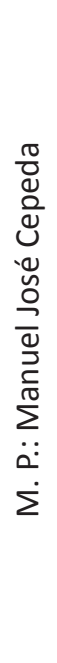 & $\begin{array}{l}\text { MINERÍA EN ZONA DE RESERVA: (i) Desde el } \\
\text { 09-03-1993 se explotaba material de construc- } \\
\text { ción en La Calera, Cundinamarca, con todos los } \\
\text { permisos mineros y ambientales requeridos } \\
\text { para ello. (ii) La CAR impuso medida preventiva } \\
\text { de suspensión de minería por incumplimiento } \\
\text { en el Plan de Manejo Ambiental y encontrarse } \\
\text { en una zona de reserva forestal protectora. (iii) } \\
\text { Ciudadano instaura acción de cumplimiento } \\
\text { contra el Minminas para que desaloje las zonas } \\
\text { ambientales protegidas. (iv) Consejo de Estado } \\
\text { niega la solicitud por no encontrarse esas zonas } \\
\text { geográficamente delimitadas. }\end{array}$ & $\begin{array}{l}\text { La Corte cita la sentencia C-293/02 que decide } \\
\text { la exequibilidad del artículo } 1.6 \text { de la Ley 99/93 } \\
\text { y la C-339/02 como jurisprudencias relevantes } \\
\text { en el asunto. Sin embargo, no especifica cómo } \\
\text { se aplica esto al caso concreto más allá de jus- } \\
\text { tificar formalmente la actuación de la CAR para } \\
\text { imponer las medidas, con fundamento en el } \\
\text { principio de precaución. }\end{array}$ \\
\hline
\end{tabular}




\begin{tabular}{|c|c|c|c|}
\hline 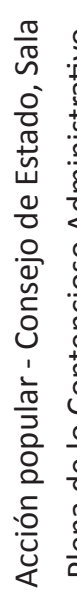 & 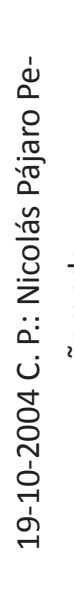 & $\begin{array}{l}\text { ASPERSIONES AÉREAS CON SUSTANCIAS TÓXI- } \\
\text { CAS: (i) Se han realizado fumigaciones aéreas } \\
\text { con paraquat y glifosato en algunas áreas donde } \\
\text { hay cultivos de coca y amapola. (ii) EI Minambi- } \\
\text { ente no ha realizado el control y seguimiento de } \\
\text { esta actividad. (iii) "La aspersión aérea destruye } \\
\text { el medio ambiente y aumenta la tragedia hu- } \\
\text { mana de quienes reciben los efectos de los } \\
\text { químicos asperjados". (iv) Se han utilizado "mi- } \\
\text { croherbicidas que tienen el carácter de armas } \\
\text { biológicas". }\end{array}$ & $\begin{array}{l}\text { Se justifica la aplicación del principio aunque } \\
\text { las pruebas indiquen que la fumigación "no } \\
\text { tiene impactos graves e irreversibles en los } \\
\text { diferentes componentes del medio ambiente" } \\
\text { y no haya certeza absoluta de las consecuen- } \\
\text { cias de la fumigación. Así, las autoridades } \\
\text { deben tomar "medidas eficaces para evitar } \\
\text { la degradación del medio ambiente, lo cual } \\
\text { suele ocurrir frente a actividades humanas } \\
\text { que operan en gran escala sobre elementos } \\
\text { del medio ambiente y cuya carencia de efectos } \\
\text { graves e irreversibles requiere verificación per- } \\
\text { manente". }\end{array}$ \\
\hline 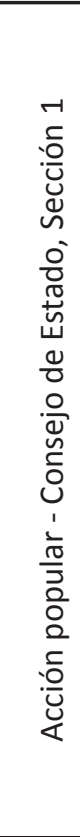 & 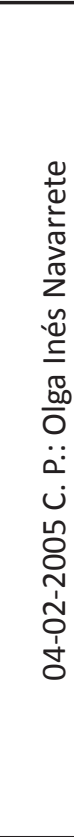 & $\begin{array}{l}\text { ORGANISMOS VIVOS GENÉTICAMENTE MODI- } \\
\text { FICADOS: (i) En abril de } 1999 \text { una empresa } \\
\text { solicita al ICA autorización para introducir, pro- } \\
\text { ducir y comercializar algodón genéticamente } \\
\text { modificado, resistente a unos insectos gracias } \\
\text { al gen de una bacteria. (ii) El ICA ordenó evaluar } \\
\text { los riesgos y el efecto sobre las poblaciones de } \\
\text { los cultivos de algodón. (iii) Minambiente re- } \\
\text { comendó adelantar más ensayos. (iv) El } 10 \text { de } \\
\text { mayo de } 2002 \text {, el ICA autoriza la importación de } \\
\text { hasta } 50.000 \text { Kgm de semilla de algodón gené- } \\
\text { ticamente modificado. }\end{array}$ & $\begin{array}{l}\text { NO hay unanimidad en cuanto a las conse- } \\
\text { cuencias de la introducción de organismos vi- } \\
\text { vos genéticamente modificados que al tratarse } \\
\text { de cultivos, intentan "aumentar y mejorar la } \\
\text { producción de cosechas que se utilizan en la } \\
\text { alimentación". El Consejo de Estado resalta que } \\
\text { debe tenerse cuidado con los impactos en el } \\
\text { medio ambiente y la biodiversidad que estos } \\
\text { puedan tener. Teniendo en cuenta el enfoque } \\
\text { de precaución que se encuentra expresamente } \\
\text { establecido en la Ley } 740 \text { de } 2002 \text {, que aprobó } \\
\text { el Protocolo de Cartagena sobre Seguridad de } \\
\text { la Biotecnología, se ordena la conformación de } \\
\text { un comité especial para el seguimiento de las } \\
\text { actividades de la empresa importadora del al- } \\
\text { godón. }\end{array}$ \\
\hline 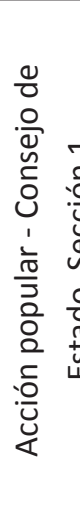 & 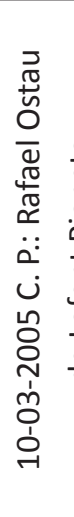 & $\begin{array}{l}\text { MANEJO DE RESIDUOS: el matadero del muni- } \\
\text { cipio de Coello se encuentra en una zona ur- } \\
\text { bana, no tiene condiciones para garantizar la } \\
\text { calidad de la carne y sin tratamiento adecuado } \\
\text { de residuos. }\end{array}$ & $\begin{array}{l}\text { Se aplica el principio de precaución para evitar } \\
\text { un posible impacto negativo como consecuen- } \\
\text { cia de la actividad desarrollada en el matadero. } \\
\text { Por la forma como se adelantan los proced- } \\
\text { imientos se podrían afectar las condiciones de } \\
\text { salubridad de la carne. Con fundamento en ello, } \\
\text { el Consejo de Estado decide exhortar al alcalde } \\
\text { del municipio para que disponga la partida pre- } \\
\text { supuestal y realice los trámites ante el Concejo } \\
\text { para la construcción del nuevo matadero. }\end{array}$ \\
\hline
\end{tabular}




\begin{tabular}{|c|c|c|c|}
\hline 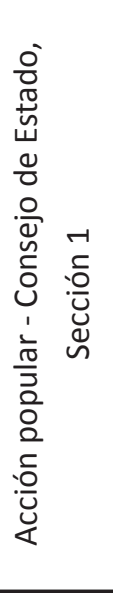 & 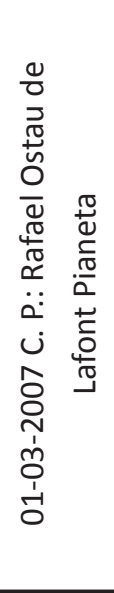 & $\begin{array}{l}\text { MANEJO DE RESIDUOS: (i) Contrario a lo } \\
\text { que certifica la Secretaría de Salud del } \\
\text { departamento, el hospital del municipio San } \\
\text { Martín no incinera los residuos hospitalarios y } \\
\text { similares ni está utilizando ningún método de } \\
\text { desactivación para la disposición final de los } \\
\text { residuos. (ii) El municipio de San Martín no } \\
\text { cuenta con relleno sanitario. }\end{array}$ & $\begin{array}{l}\text { El Consejo de Estado cita el Decreto } 2676 \text { del } \\
22 \text { de } 2000 \text {, especialmente los artículos } 3 \text { y } 4 \\
\text { que se refieren a la precaución. No obstante lo } \\
\text { anterior, se confirma el fallo que declaró como } \\
\text { no acreditado el mal manejo de los desechos } \\
\text { por parte del hospital y por el contrario se } \\
\text { considera que sí se acreditó su cumplimiento. } \\
\text { Esto, desconociendo lo argumentado en líneas } \\
\text { anteriores por el mismo Consejo de Estado en } \\
\text { cuanto al principio de precaución y concluy- } \\
\text { endo que "el incumplimiento de una norma no } \\
\text { implica per se la vulneración de los derechos } \\
\text { de tercera generación, sino que se debe probar } \\
\text { que tal situación genera un riesgo o amenaza". }\end{array}$ \\
\hline 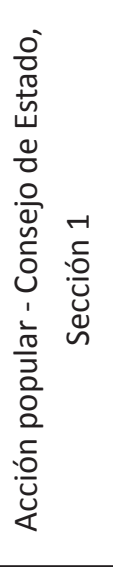 & 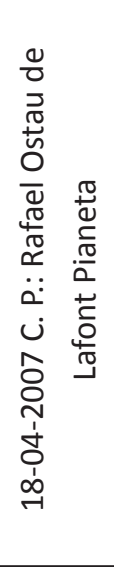 & $\begin{array}{l}\text { AGUA/RESIDUOS: (i) El río La Paila es contami- } \\
\text { nado en el municipio de Puerto Tejada por el } \\
\text { vertimiento de aguas servidas de los barrios } \\
\text { aledaños, los residuos del matadero municipal } \\
\text { y los residuos del hospital local. (ii) Hay con- } \\
\text { taminación por olores fétidos. (iii) El municipio } \\
\text { de Puerto Tejada y la Corporación Autónoma } \\
\text { Regional del Cauca permiten que las personas } \\
\text { contaminen el río. }\end{array}$ & $\begin{array}{l}\text { Se otorga un alcance limitado al principio, ya } \\
\text { que solo se confirma la sentencia apelada según } \\
\text { la cual las autoridades ambientales tomaron } \\
\text { medidas para afrontar la situación "que si bien } \\
\text { no han sido solución definitiva, contribuyen a } \\
\text { mantener el equilibrio ecológico y darle una ad- } \\
\text { ecuada utilización a los recursos". El Consejo de } \\
\text { Estado exhorta al municipio y a la Corporación } \\
\text { a gestionar de manera prioritaria los recursos } \\
\text { para la correcta disposición de los residuos de } \\
\text { municipio y el hospital. }\end{array}$ \\
\hline 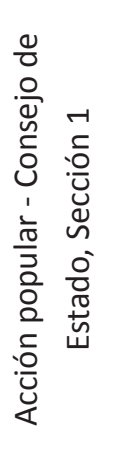 & 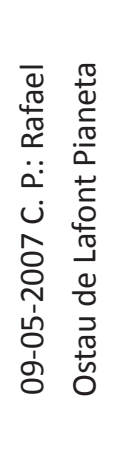 & $\begin{array}{l}\text { MANEJO DE RESIDUOS: (i) Contrario a lo que } \\
\text { certifica la Secretaría de Salud del departamen- } \\
\text { to, el hospital del municipio de Tamalameque } \\
\text { no incinera los residuos hospitalarios y simil- } \\
\text { ares ni está utilizando ningún método de desac- } \\
\text { tivación para la disposición final de los residuos. } \\
\text { (ii) El municipio de Tamalameque no cuenta con } \\
\text { un relleno sanitario apropiado. }\end{array}$ & $\begin{array}{l}\text { El Consejo de Estado cita los artículos } 3 \text { y } 4 \text { de } \\
\text { Decreto } 2676 \text { del } 22 \text { de } 2000 \text { referentes al prin- } \\
\text { cipio de precaución. No obstante lo anterior, se } \\
\text { confirma el fallo que declaró como no acredita- } \\
\text { do mal manejo de los desechos, pues el hospita } \\
\text { tiene un contrato con una empresa recolectora } \\
\text { de basuras que los lleva a un relleno en la ciu- } \\
\text { dad de Cúcuta donde se cumplen las condicio- } \\
\text { nes adecuadas para su disposición final. }\end{array}$ \\
\hline
\end{tabular}




\begin{tabular}{|c|c|c|c|}
\hline 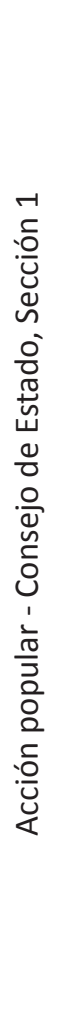 & 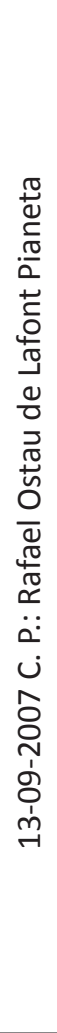 & $\begin{array}{l}\text { MANEJO DE RESIDUOS: (i) El hospital del mu- } \\
\text { nicipio de La Paz no incinera los residuos hos- } \\
\text { pitalarios y similares ni está utilizando ningún } \\
\text { método de desactivación para la disposición } \\
\text { final de los residuos. (ii) El municipio de La Paz } \\
\text { no cuenta con un relleno sanitario apropiado. }\end{array}$ & $\begin{array}{l}\text { El Consejo de Estado cita el Decreto } 2676 \text { del } \\
2000 \text { que regula lo referente a la disposición de } \\
\text { los residuos hospitalarios y que menciona ex- } \\
\text { presamente el principio de precaución. Según } \\
\text { el material probatorio aportado, se considera } \\
\text { que el hospital demandado ha cumplido con } \\
\text { la gestión interna en el manejo de los residuos, } \\
\text { realizando todas las actividades tendientes a la } \\
\text { desactivación y almacenamiento interno, así } \\
\text { como la incineración de basuras. Con poste- } \\
\text { rioridad a la presentación de la acción popular } \\
\text { el hospital celebró un contrato para la gestión } \\
\text { externa de los residuos, que consiste en la re- } \\
\text { colección, transporte e incineración. Por esto } \\
\text { último, se ampara el derecho colectivo pues } \\
\text { se considera que sin la acción los residuos hos- } \\
\text { pitalarios hubiesen seguido generando un im- } \\
\text { pacto ambiental negativo. Sin embargo, no hay } \\
\text { condenas pues ya se han tomado las medidas } \\
\text { para proteger el derecho colectivo. }\end{array}$ \\
\hline
\end{tabular}




\begin{tabular}{|c|c|c|c|}
\hline 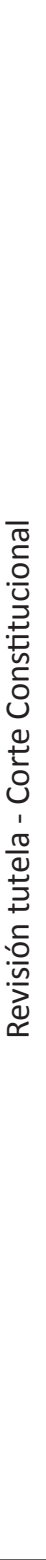 & 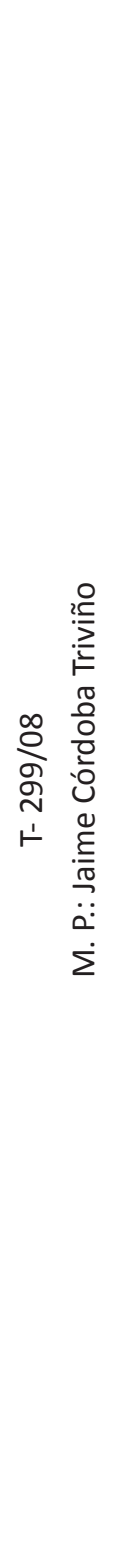 & $\begin{array}{l}\text { SALUD/CONTAMINACIÓN ELECTROMAGNÉ- } \\
\text { TICA: (i) Accionantes viven cerca de una sub- } \\
\text { estación eléctrica de Codensa S. A. (ii) Con el } \\
\text { uso de los electrodomésticos se presentan des- } \\
\text { cargas inusuales de corriente. }\end{array}$ & $\begin{array}{l}\text { El derecho internacional introdujo el principio } \\
\text { de precaución cuyos elementos son: (i) amen- } \\
\text { aza de peligro grave al medio ambiente o la } \\
\text { salud, (ii) inexistencia de certeza científica, (iii) } \\
\text { impone a las autoridades la adopción de medi- } \\
\text { das de protección. } \\
\text { El principio se incorporó a la legislación colom- } \\
\text { biana a partir de la suscripción de la Declara- } \\
\text { ción de Río, la expedición de la Ley } 99 \text { de } 1993 \\
\text { y mediante el examen de constitucionalidad de } \\
\text { algunas normas. } \\
\text { Este principio constitucional es un mecanismo } \\
\text { de interpretación al momento de determinar si } \\
\text { es necesaria la intervención de las autoridades } \\
\text { en asuntos del medio ambiente y la salud como } \\
\text { un "enfoque excepcional y alternativo frente al } \\
\text { principio de certeza científica". } \\
\text { Frente a las críticas planteadas al principio, la } \\
\text { Corte responde argumentando que: (i) No con- } \\
\text { stituye una renuncia a la certeza científica pues- } \\
\text { to que las decisiones tomadas en virtud de este } \\
\text { son provisionales. (ii) Las medidas derivadas } \\
\text { del principio no son caprichosas e injustificadas } \\
\text { porque su utilización requiere elementos cientí- } \\
\text { ficos que indiquen al menos la necesidad de in- } \\
\text { tervención y la potencialidad del daño con fun- } \\
\text { damento en criterios de razonabilidad. (iii) Los } \\
\text { costos de su aplicación deben ser analizados } \\
\text { póblica y teniendo en cuenta el }\end{array}$ \\
\hline
\end{tabular}




\begin{tabular}{|c|c|c|c|}
\hline 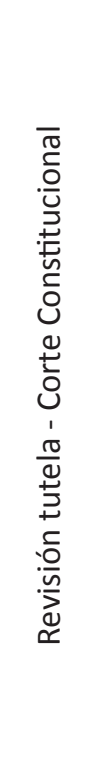 & 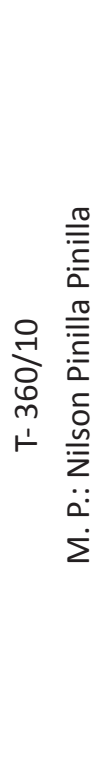 & $\begin{array}{l}\text { SALUD/CONTAMINACIÓN ELECTROMAGNÉ- } \\
\text { TICA: (i) Accionante vive a } 76 \text { m de una torre de } \\
\text { telefonía móvil. (ii) Accionante fue operada por } \\
\text { una enfermedad coronaria y le implantaron un } \\
\text { cardiodesfibrilador. (iii) Como consecuencia de } \\
\text { la alta radiación el dispositivo implantado solo } \\
\text { duró un mes. (iv) La empresa de telefonía móvil } \\
\text { responde que "sus campos electromagnéticos } \\
\text { emitidos cumplen con los límites de exposición } \\
\text { pertinentes y no son necesarias precauciones } \\
\text { particulares". }\end{array}$ & $\begin{array}{l}\text { A falta de certeza científica debe aplicarse el } \\
\text { principio de precaución contemplado en los } \\
\text { mecanismos internacionales, y aceptado por la } \\
\text { jurisprudencia. Esto, para justificar que aunque } \\
\text { no haya certeza "de que las ondas de radiofre- } \\
\text { cuencia generadas por las estaciones base de } \\
\text { telefonía móvil generen efectos negativos a } \\
\text { largo plazo para la salud de la población". Por } \\
\text { ello, se exhorta al MinTic para que diseñe "un } \\
\text { proyecto encaminado a establecer una distan- } \\
\text { cia prudente entre las torres de telefonía móvil } \\
\text { y las instituciones educacionales, hospitales, } \\
\text { hogares geriátricos y centros similares" pues allí } \\
\text { se encuentra la población más vulnerable a la } \\
\text { radiación de ondas electromagnéticas. }\end{array}$ \\
\hline 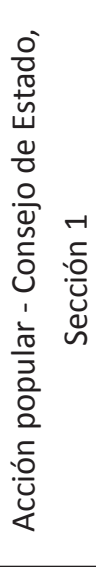 & 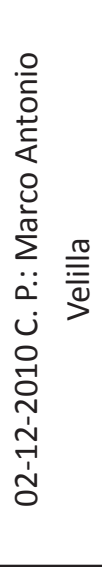 & $\begin{array}{l}\text { RESIDUOS/SALUD: (I) El área donde una em- } \\
\text { presa incineradora de residuos ejerce su activi- } \\
\text { dad en el municipio de Itagüi está ubicada con- } \\
\text { traviniendo los usos del suelo. (ii) Planeación } \\
\text { Municipal concedió el permiso de ubicación } \\
\text { industrial y calificó la actividad como de alto } \\
\text { potencial contaminante. (iii) La empresa está } \\
\text { ocupando otros predios además del autorizado. } \\
\text { (v) Cerca al sector hay conglomerados urbanos } \\
\text { multifamiliares. }\end{array}$ & $\begin{array}{l}\text { El actor solicita la aplicación del principio de } \\
\text { precaución pero el Consejo de Estado considera } \\
\text { que no hay lugar puesto que no se cumple con } \\
\text { los siguientes requisitos: "1. Que la actividad } \\
\text { genere peligro } 2 \text {. Que sea grave e irreversible } \\
\text { 3. Que no exista un principio de certeza cientí- } \\
\text { fica". No hay evidencia de que se amenacen los } \\
\text { derechos colectivos y, por el contrario, la em- } \\
\text { presa desarrolla su actividad en cumplimiento } \\
\text { de tales derechos. No se logró probar que su } \\
\text { actividad genere enfermedades a las familias. }\end{array}$ \\
\hline 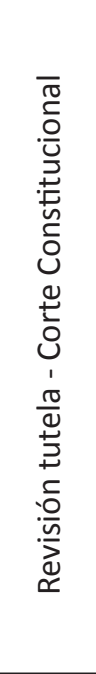 & 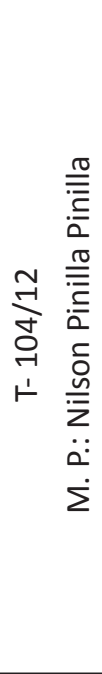 & $\begin{array}{l}\text { SALUD/CONTAMINACIÓN ELECTROMAGNÉ- } \\
\text { TICA: (i) La madre de un menor que vivía en el } \\
\text { hogar comunitario del ICBF en el municipio de } \\
\text { Matanza asegura que las instalaciones no son } \\
\text { adecuadas para los niños. (ii) Que el hogar se } \\
\text { encuentra ubicado muy cerca de unas antenas } \\
\text { parabólicas. }\end{array}$ & $\begin{array}{l}\text { Se reitera la jurisprudencia que reconoce que } \\
\text { cuando los "campos electromagnéticos emiti- } \\
\text { dos cumplen con los límites de exposición per- } \\
\text { tinentes, no son necesarias precauciones par- } \\
\text { ticulares" pero que a falta de certeza científica } \\
\text { debe aplicarse el principio de precaución con- } \\
\text { templado en los mecanismos internacionales y } \\
\text { aceptado por la jurisprudencia. Por ello la Corte } \\
\text { ordena al municipio de Matanza reubicar las } \\
\text { antenas parabólicas en un lugar alejado de las } \\
\text { poblaciones vulnerables a las radiaciones, en el } \\
\text { plazo de } 3 \text { meses y solicita al Concejo Municipal } \\
\text { regular sobre el particular. }\end{array}$ \\
\hline
\end{tabular}




\begin{tabular}{|c|c|c|c|}
\hline 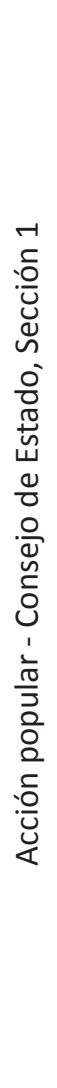 & 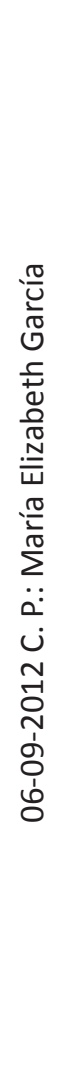 & $\begin{array}{l}\text { BIODIVERSIDAD: (i) El tiburón es apetecido en } \\
\text { el mercado y susceptible de sobrepesca por ser } \\
\text { de crecimiento lento, de madurez sexual tardía, } \\
\text { con baja fecundidad y potencial reproductivo. } \\
\text { (ii) En los últimos siete años se ha aumentado la } \\
\text { pesca de tiburón a nivel industrial. (iii) Se debe } \\
\text { aplicar el principio de precaución pues se corre } \\
\text { el riesgo de la extinción. (iv) La pesca de tiburón } \\
\text { se ejerce capturando especímenes jóvenes y } \\
\text { usando "una palangre (línea) horizontal de fon- } \\
\text { do de más de } 15 \text { kilómetros que al emplearse } \\
\text { en ambientes coralinos produce frecuent- } \\
\text { emente destrucción, fragmentación y volca- } \\
\text { miento de los mismos" que la hacen altamente } \\
\text { impactante. (v) La Secretaría de Agricultura y } \\
\text { Pesca del departamento de San Andrés y Provi- } \\
\text { dencia recomendó prohibir la pesca dirigida de } \\
\text { tiburones en el archipiélago. (vi) El Minagricul- } \\
\text { tura estableció que el archipiélago tiene cuota } \\
\text { de pesca de tiburón abierta (sin límite). }\end{array}$ & $\begin{array}{l}\text { Se utiliza la definición de precaución contenida } \\
\text { en el principio } 15 \text { de la Declaración de Río y se } \\
\text { cita la sentencia C-293/02 en la que se concluye } \\
\text { que la autoridad debe tomar decisiones para } \\
\text { evitar un peligro de daño grave, aun sin contar } \\
\text { con la certeza científica absoluta, siguiendo la } \\
\text { Constitución y la ley y hacerlo en forma moti- } \\
\text { vada y excepcional. El Minambiente se encarga } \\
\text { de adoptar las medidas para asegurar la protec- } \\
\text { ción de las especies y para ello cuenta con el } \\
\text { apoyo técnico y científico de varios institutos, } \\
\text { centros de investigaciones ambientales y de las } \\
\text { universidades. } \\
\text { El Consejo de Estado concuerda con el accio- } \\
\text { nante en que "administrar de manera respon- } \\
\text { sable las pesquerías" es complejo y ya que no } \\
\text { hay suficiente información sobre estos recursos } \\
\text { se debe adoptar un enfoque de precaución. Por } \\
\text { lo anterior y por ser el archipiélago una reserva } \\
\text { de la biosfera, se prohíbe la pesca industrial de } \\
\text { tiburones. }\end{array}$ \\
\hline
\end{tabular}




\begin{tabular}{|c|c|c|c|}
\hline 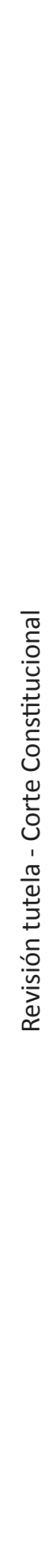 & 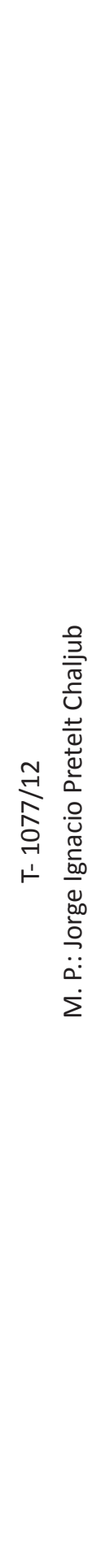 & $\begin{array}{l}\text { SALUD/CONTAMINACIÓN } \quad \text { ELECTROMAGNÉ- } \\
\text { TICA: (i) Menor de } 15 \text { años que desde los } 12 \text { fue } \\
\text { diagnosticada con cáncer incurable, (ii) entre las } \\
\text { recomendaciones de su oncólogo se encuentra } \\
\text { la de "evitar al máximo cualquier exposición a } \\
\text { radiofrecuencias", (iii) a } 41 \text { metros de su casa } \\
\text { existe un predio propiedad de Telefónica Tele- } \\
\text { com S. A. E. S. P. en donde hay instalados instru- } \\
\text { mentos que emiten señales electromagnéticas } \\
\text { sin permiso de la Secretaría de Planeación Mu- } \\
\text { nicipal. }\end{array}$ & 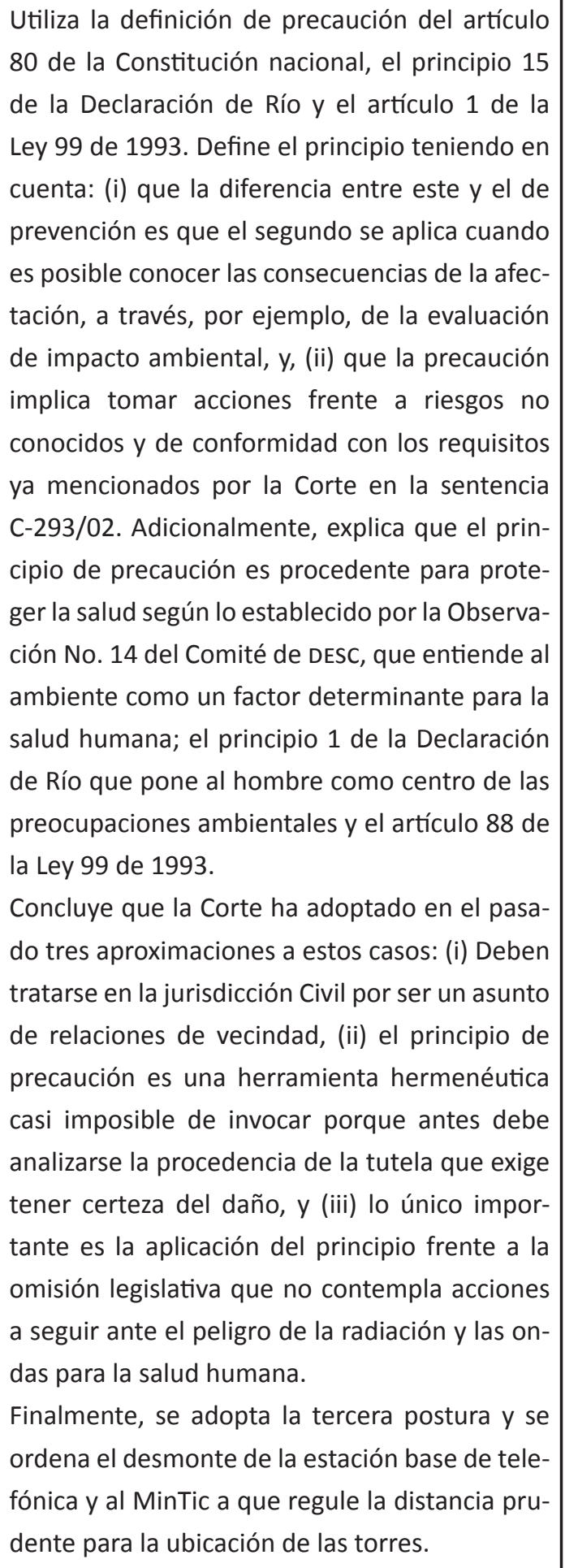 \\
\hline
\end{tabular}


Respecto al cuadro anterior vale la pena resaltar algunas conclusiones preliminares:

- No en todas las oportunidades el Consejo de Estado y la Corte Constitucional han utilizado el principio de precaución de la misma manera. Si bien la definición de este casi siempre es la misma, su materialización en los casos concretos se presenta de diversas formas: en algunos se limitan a mencionarlo y luego no lo aplican en la solución, en otros lo definen pero no condenan al accionado por no encontrarse pruebas del peligro estando esto en contravía del principio, y pocas veces lo utilizan como fundamento para amparar el derecho colectivo al medio ambiente sano. Esto significa que hay "una precaria, por no decir nula, aplicación directa (per se), es decir, con su sola enunciación y correspondiente análisis, como sucede con otros principios (de legalidad, buena fe, tipicidad en el derecho penal). De esta manera, el principio de precaución -si se ha incluido en el fallo- se ve prácticamente reducido a un simple obiter dicta" (Rodríguez, 2012, p. 86.)

- Son las autoridades ambientales como las Corporaciones Autónomas Regionales y el Ministerio de Medio Ambiente, a través de la Agencia Nacional de Licencias Ambientales, las que usualmente se encargan de aplicar el principio a través del monitoreo de todas las actividades industriales con potenciales impactos ecológicos. No obstante lo anterior, ya se ha aclarado que en este documento no se analizaron actos administrativos particulares sino precedentes judiciales proferidos a propósito de casos concretos. Esto, con el ánimo de concentrarse en las decisiones que, aunque también son particulares, tienen carácter vinculante de conformidad con lo establecido por la misma Corte Constitucional en sentencia T-960 de 2001, en la que se dijo que esta fuerza "se predica en la ratio decidendi" y en la T-1317 de 2001 que precisa que lo es para todos los casos en los cuales los hechos determinantes concuerden con los elementos fácticos de los que trata el precedente.

- Además de citar los convenios internacionales relevantes en la mayoría de los casos específicos, tanto la Corte como el Consejo de Estado se refieren en repetidas oportunidades a algunos fallos en materia de constitucionalidad que tratan el principio de precaución. En esa compilación incluyen las siguientes sentencias de constitucionalidad, muchas de las cuales ya fueron mencionadas en capítulos anteriores de este documento: (i) C-073/95 que estudia la constitucionalidad de la Ley 164 de 1994 que aprueba la Convención Marco de las Naciones Unidas sobre la Protección al Medio Ambiente; (ii) C-671/01 que sin mencionar expresamente el principio de precaución resalta la obligación de acudir a los principios de derecho internacional en lo que la Corte ha denominado "la internacionalización de las relaciones ecológicas"; (iii) C-293/02 que analiza la constitucionalidad del principio de precaución contemplado en el artículo 1.6 de la Ley 99 de 1993; (iv) C-339/02 en la que la Corte ordenó seguir el principio de precaución en la definición de las zonas de exclusión minera de la Ley 685 de 2001; (v) C-071/03 que examina la constitucionalidad de la Ley aprobatoria del Protocolo de Cartagena 
sobre seguridad biológica; y (vi) C-988/04 sobre el registro de agroquímicos genéricos potencialmente dañinos para el medio ambiente y la salud pública.

- La Corte Constitucional utiliza criterios más exigentes cuando se trata de proteger el derecho al medio ambiente sano por vía tutela, que los que usualmente llevan al Consejo de Estado a condenar en las acciones populares. Lo anterior, pues tal como ya se ha explicado, por ser este un derecho colectivo debe encontrarse en conexidad con otro fundamental, como la salud o la vida digna, para que sea la tutela el instrumento adecuado para su protección. Esto, sumado a la naturaleza especialísima y subsidiaria de la acción constitucional.

\section{CONCLUSIONES}

Para finalizar el presente escrito y antes de intentar brindar una respuesta al problema jurídico planteado, se presentarán algunas conclusiones que pueden extraerse de lo dicho hasta el momento en cada uno de los capítulos precedentes.

En cuanto a los antecedentes y generalidades del principio de precaución vale la pena recordar que, aunque este concepto tuvo su origen en las jurisdicciones locales, fue en el ámbito internacional en el que alcanzó su mayor aceptación. Esto, en un contexto en el que las preocupaciones por el entorno se mezclaron con elementos culturales, sociales, económicos y científicos durante la última década del siglo xx y comenzaron a aparecer diversos instrumentos internacionales que hacian referencia en primera medida a la prevención y posteriormente de manera más refinada a la precaución.

Pese a su consagración en múltiples instrumentos, no es posible afirmar que el enfoque de precaución haya pasado a ser un principio de derecho internacional en el sentido preciso del término. Lo anterior, a propósito de su amplia definición y de la manera como ha sido entendido por algunos países que reiteradamente han negado su aplicación en contextos diferentes al estrictamente ambiental y han sometido sus consecuencias a la aplicación provisional de este. De allí que una primera conclusión sea que el principio 15 de la Declaración de Río no ha tenido una aceptación uniforme por parte de la comunidad y los organismos internacionales ni de las naciones individualmente consideradas que le han dado diversos alcances al interior de sus ordenamientos jurídicos.

No obstante, vale la pena mencionar sobre este punto que por regla general el principio de precaución se activa según la fórmula de Reffensperger así (Rodríguez, 2012, p. 38): Incertidumbre científica + sospecha de daño = acción precaudatoria.

Según esto y teniendo en cuenta el lenguaje, a lo largo del texto se identificaron tres elementos fundamentales en la definición de precaución: el riesgo como aquello que le otorga significado al principio, el daño como materialización de ese riesgo, y la incertidumbre científica como la condición sin la cual no se puede aplicar la precaución. Con base en ellos es posible determinar los diferentes niveles de afectación al 
ambiente que se consideran como exposición o puesta en peligro, así como las medidas que se pueden utilizar para evitarlo.

Un aspecto importante de este documento ha sido la advertencia acerca de la utilización del término prevención de manera casi irrestricta, su confusión con el de precaución y viceversa. Al respecto, se mencionó en su momento que la gran diferencia entre uno y otro se encontraba en el nivel de certidumbre científica que se tenía al momento de su aplicación. Si técnicamente es posible determinar el daño que ocasionaría una determinada actividad, entonces la palabra adecuada es "prevención", mientras que si lo que se tiene es solo una probabilidad o posibilidad pero sin resultados concretos, se utiliza el vocablo “precaución”. Adicionalmente, tal como se mostró en la tabla 2 , son también características importantes en esta diferenciación el nivel de riesgo y algunas veces, la temporalidad.

Para concluir, aunque el principio de precaución se encuentra redactado de manera ambigua y por ello en muchas oportunidades se ha criticado su aplicación, este encuentra sus límites en la proporcionalidad entre las medidas a tomar y el nivel de protección deseado por la autoridad. De la misma manera, se ha entendido que las decisiones no pueden ser discriminatorias, deberán mantenerse consistentes y no podrán prolongarse indefinidamente en el tiempo.

Otro gran bloque de consideraciones presentadas en este trabajo se relaciona con la introducción del principio de precaución en el derecho ambiental colombiano. En primer lugar, se tiene que este llega a nuestro país no solo mediante la introducción de los tratados internacionales, sino también gracias al tinte ecológico de la Constitución de 1991 y la jurisprudencia de la Corte Constitucional referente a las decisiones de constitucionalidad de las diversas normas relativas al medio ambiente. Adicionalmente, se evidenció que además de la Ley 99 de 1993 el principio de precaución no aparece mencionado expresamente en las principales leyes que regulan la materia, pues ni en el régimen sancionatorio ni en el de licenciamiento se utiliza este concepto y en su lugar se menciona el de prevención.

Por último, en el recuento jurisprudencial se aterrizó el principio a los casos particulares en los cuales el Consejo de Estado a través de las acciones populares y la Corte Constitucional por vía de tutela han entendido el principio de precaución. De allí no pudo obtenerse una conclusión tan clara, pues a pesar de que en cada uno de los fallos se definió el principio de conformidad con la manera como fue consagrado en la Declaración de Río y posteriormente en la Ley 99 de 1993, no siempre se le otorgó el mismo alcance e incluso en algunos casos se falló en contravía de sus planteamientos.

De conformidad con todo lo anterior, es posible mencionar que se han identificado algunos de los elementos negativos y positivos del principio de precaución para determinar su alcance. Por ello, la respuesta al gran problema jurídico que se planteó desde el comienzo es que si bien no se está en el peor de los escenarios, en el cual existe una indeterminación absoluta de los límites del principio de precaución, tampoco hay una sola o única solución que permita delinear 
sus consecuencias, el ámbito de aplicación ni las situaciones en las cuales debe ser invocado.

Esto, ya que no hay tampoco una respuesta definitiva a las preguntas de cómo saber que realmente hay un daño ambiental significativo y cómo calcular los costos ambientales ante la falta de certeza científica. En todo caso, siempre existirán indicios que dependerán de cada situación concreta pero que nunca podrán ser condensados en una regla jurídica que permita afirmar, más allá de toda duda, que el principio de precaución ha dejado de lado sus elementos más enigmáticos. Tampoco, que ha sido definido de forma absolutamente concreta, bien sea mediante un instrumento de derecho internacional que haga parte de nuestro ordenamiento jurídico gracias a la internacionalización de las relaciones ecológicas ordenada por el artículo 226 constitucional, o por una norma interna de carácter general expedida por los organismos competentes para hacerlo.

\section{Bibliografía}

\section{Libros:}

Amaya Navas, Ó. D. (2010). La constitución ecológica de Colombia. Bogotá: Universidad Externado de Colombia.

De la Calle Lombana, H. (2004). Contra todas las apuestas: historia íntima de la constituyente de 1991. Bogotá: Editorial Planeta.

Eco, H. (2001). Cómo se hace una tesis: técnicas y procedimientos de estudio, investigación y escritura. Barcelona: Gedisa Editorial.
Federovisky, S. (2007). Historia del medio ambiente. Buenos Aires: Capital Intelectual, Estación Ciencia.

Flórez Malagón, A. (2000). Ambiente y desarroIlo, ensayos III: El campo de la historia ambiental, perspectivas para su desarrollo en Colombia. Bogotá: Pontificia Universidad Javeriana e IDEANE.

Jiménez de Parga y Maseda, P. (2001). El principio de prevención en el derecho internacional del medio ambiente. Madrid: Editoriales Ecoiuris.

Macías Gómez, L. F. (1998). Introducción al derecho ambiental: incluye convenios internacionales. Bogotá: Editorial Legis.

Richmann, J. \& Tickner, J. (Coord.). (2002). El principio de precaución en medio ambiente y salud pública: de las definiciones a la práctica. Barcelona: Editorial Ikaria.

Rodríguez, G. A., Gómez Rey, A., Monroy Rosas, J. C. (2012). Las licencias ambientales en Colombia: una mirada desde la participación y la responsabilidad. Bogotá: Foro Nacional Ambiental. Grupo Editorial Ibánez.

Rodríguez, G. A., Páez, I. A. (2012). Temas de derecho ambiental: una mirada desde lo público. Bogotá: Universidad del Rosario, Facultad de Jurisprudencia.

Sans, P. (2003). Principles of International Environmental Law. Nueva York: Cambridge University Press. 
Sunstein, C. R. (2009). Leyes de miedo: Más allá del principio de precaución. Madrid: Editorial Katz.

Uribe Vargas, D. (2010). Derecho Internacional Ambiental. Bogotá: Universidad de Bogotá Jorge Tadeo Lozano.

\section{Artículos en línea:}

Abbott, K., Snidal, D. (2000). Hard and soft law in international governance. The 10 Foundation and the Massachusetts Institute of technology. International organization 54,3, pp. 421-456. Recuperado el 4 de octubre 2012, de: http://web.efzg.hr/dok/pra/hhorak/Hard\%20and\%20soft\%20law\%20in\%20 international\%20governance.pdf

Actas de la Mesa Redonda de la Geneva Environment Network. (2002). La Precaución: de Río a Johannesburgo. Recuperado el 20 de agosto de 2012, de: http://environmenthouse.ch/docspublications/reportsRoundtables/Precaution\%20Report\%20s.pdf.

Cajicas-Rotundo, J. C. (s. f.). Pensamiento ecoIógico. Recuperado el 20 de agosto de 2012, de: http://www.ensayistas.org/critica/ecologia/cajigas.htm.

Carreño Bustamante, M. T. (2010). El papel de la participación ciudadana en la eficacia de las decisiones político-administrativas y ambientales en la protección del derecho a un ambiente sano de las comunidades ubicadas alrededor de la quebrada Manizales en la zona industrial de Maltería (Manizales, Colombia).
Ambiente jurídico No 12, Centro de Investigaciones Sociojurídicas. Pp. 190-204. Recuperado el 4 de octubre 2012, de: http://www. lexbasecolombia.net.bxaiblioteca.uniandes. edu.co:8080/revistauniversitaria/umanizales/ambiente\%20juridico\%202010/el\%20 papel\%20de\%20la\%20participacion\%20ciudadana.htm

Cooney, R. (2004). El principio de precaución en la conservación de la biodiversidad y la gestión de los recursos naturales: documento dirigido a responsables políticos, investigadores y profesionales. Unión Internacional para la Conservación de la Naturaleza. Recuperado el 25 de septiembre 2012, de: http:// www.mamacoca.org/docs_de_base/Legislacion_tematica/elprincipiodeprecaucion.pdf

Dupuy, P. (1991). Soft law and the international law of the environment. Michigan Journal of International Law, Vol. 12, Issue 2. Pp. 420435. Recuperado el 4 de octubre 2012, de: http://heinonline.org.biblioteca.uniandes. edu.co:8080/HOL/Page?handle=hein.journals $/$ mjil $12 \&$ div $=20 \&$ collection=journals $\& s$ et_as_cursor $=0 \&$ men_tab=srchresults \&ter ms $=$ Soft $\mid$ Law $\mid$ and $\mid$ the $\mid$ International $\mid$ Law $\mid 0$ $\mathrm{f} \mid$ the $\mid$ Environment\&type=matchall

García Henao, L. (2002). Teoría del desarrollo sostenible y legislación ambiental colombiana, una reflexión cultural. Revista de Derecho No 20, Universidad del Norte de BarranquiIla. Recuperado el 25 de septiembre 2012, de: $\quad$ http://redalyc.uaemex.mx/redalyc/ pdf/851/85102008.pdf 
MacNelis, N. (2000). Eu Communications on the precautionary principle. Journal of International Environmental Law. Recuperado el 20 de agosto de 2012, de: http://heinonline.org/ $\mathrm{HOL} /$ LandingPage?collection=journals\&han dle=hein.journals $/$ jiel3\&div=52\&id=\&page.

Steele, K. (s. f.). The precautionary principle: a new approach to public decision- making? Law, probability and risk. Department of philosophy, The University of Queenslan. Recuperado el 3 de noviembre 2012, de: http:// Ipr.oxfordjournals.org

United Nations Educational, Scientific and Cultural Organization \& World Commission on the Ethics of Scientific Knowledge and Technology (comest). (2005). The Precautionary Principle. Recuperado el 25 de septiembre 2012, de: http://unesdoc.unesco.org/ images/0013/001395/139578e.pdf.

United Nations Environment Program (UNEP). Guide for negotiators of multilateral environmental agreements. Recuperado el 21 de octubre 2012, de: http://www.acpmeas.info/mwginternal/de5fs23hu73ds/progress?id=ptaT/ F7s67

United Nations Environment Program (UNEP). (2006). Multilateral Environmental Agreement: Negotiator's Handbook. University of Joensou, Department of Law. Recuperado el 21 de octubre 2012, de: http://www.unep. org/environmentalgovernance/Portals/8/ documents/NegotiatorsHandbook.pdf
Worster, D. (1990). Transformations of the Earth: Towards an agroecological perspective in history. Journal of American History. Recuperado el 13 de noviembre 2012, de: http:// www.jstor.org/discover/10.2307/2936586? uid $=3737808 \&$ uid $=2129 \&$ uid $=2 \& u i d=70 \& u$ id $=4 \&$ sid $=21101724193507$.

\section{Páginas de Internet y otras referencias:}

Diccionario de la Real Academia de la Lengua Española. [http://www.rae.es/rae.html].

Nieto, J. (Enero a junio de 2012). Curso de Derecho Internacional Ambiental. Bogotá: Universidad de los Andes.

Programa de las Naciones Unidas para el Medio Ambiente. [http://www.pnuma.org].

\section{Instrumentos internacionales:}

Acuerdo sobre la aplicación de medidas sanitarias y fitosanitarias. (1993).

Conferencia de las Naciones Unidas sobre el Medio Ambiente y el Desarrollo. Declaración de Río sobre el Medio Ambiente y el DesarroIlo. (1992).

Convención de Viena para la protección de la capa de ozono. (1985). Viena.

Convención Marco de las Naciones Unidas sobre el Cambio Climático. (1992).

Convención sobre el cambio climático. (1992). 
Convenio de Estocolmo sobre los Contaminantes Orgánicos Persistentes. (2001).

Convenio de París para la prevención de la contaminación marina de origen terrestre. (1974).

Convenio internacional relativo a la intervención en alta mar en caso de accidentes que causen contaminación por hidrocarburos. (1969).

Convenio sobre la diversidad biológica. (1992).

Convenio sobre la protección y utilización de los cursos de agua transfronterizos y de los lagos internacionales. (1992).

Declaración de La Haya de la Tercera Conferencia Internacional sobre la protección del Mar del Norte. (1990).

Protocolo de Cartagena del Convenio sobre la Diversidad Biológica. (2000).

Protocolo de Montreal relativo a las sustancias que agotan el medio ambiente. (1989).

Códigos y normas:

Consejo de Estado. Acuerdo 55 del 2003.

Constitución Política de Colombia. 1991.

Decreto 2811 de 1974. Código de Recursos Naturales.

Decreto 2820 de 2010.

Decreto 2591 de 1991.
Ley 99 de 1993.

Ley 164 de 1994.

Ley 472 de 1998.

Ley 685 de 2001.

Ley 1333 de 2009.

\section{Decisiones judiciales:}

Organización Mundial del Comercio. CE- Medidas que afectan a la carne y los productos cárnicos (hormonas). Estados Unidos y Canadá contra las Comunidades Europeas, 1998.

Tribunal Internacional del Derecho del Mar. Caso del atún de aleta azul del sur. Nueva Zelanda contra Japón y Australia contra Japón.

\section{Consejo de Estado. Sala de lo Contencioso Admi-} nistrativo, Sección Primera:

Sentencia del 13 de mayo de 2004. Consejero ponente: Rafael Ostau de Lafont Pianeta. Radicación 25000-23-24-000-1999-055701(AP-011).

Sentencia del 29 de julio de 2004. Consejero ponente: Olga Inés Navarrete Barreto. Radicación 15001-23-31-000-2003-0285-01(AP).

Sentencia del 19 de octubre de 2004. Consejero ponente: Nicolás Pájaro Peñaranda. Radicación 25000-23-25-000-2001-0022-02(AP)IJ.

Sentencia del 04 de febrero de 2005. Consejero ponente: Olga Inés Navarrete Barreto. 
Radicación 25000-23-27-000-2003-0018102(AP).

Sentencia del 10 de marzo de 2005. Consejero ponente: Rafael Ostau de Lafont Pianeta. Radicación 73001-23-31-000-2002-0140901(AP).

Sentencia del 01 de marzo de 2007. Consejero ponente: Rafael Ostau de Lafont Pianeta. Radicación 20001-23-31-000-2004-0124801(AP).

Sentencia del 18 de abril de 2007. Consejero ponente: Rafael Ostau de Lafont Pianeta. Radicación 19001-23-31-000-2003-0106201(AP).

Sentencia del 09 de mayo de 2007. Consejero ponente: Rafael Ostau de Lafont Pianeta. Radicación 20001-23-31-000-2004-0125201(AP).

Sentencia del 13 de septiembre de 2007. Consejero ponente: Rafael Ostau de Lafont Pianeta. Radicación 20001-23-31-000-200401256-01(AP).

Sentencia del 02 de diciembre de 2010. Consejero ponente: Marco Antonio Velilla Moreno. Radicación 05001-23-31-000-2003-0366401.

Sentencia del 06 de septiembre de 2012. Consejero ponente: María Elizabeth García. Radicación 88001-23-31-000-2011-0000901(AP).

\section{Corte Constitucional:}

Sentencias de constitucionalidad

Sentencia C-126 del 1 de abril de 1998. Magistrado Ponente: Alejandro Martínez Caballero. Expediente D-1794.

Sentencia C-189 del 15 de marzo de 2006. Magistrado Ponente: Rodrigo Escobar Gil. Expediente D-5948.

Sentencia C-1189 del 13 de septiembre de 2000. Magistrado Ponente: Carlos Gaviria Díaz. Expediente D-2858.

Sentencia C-012 del 17 de enero de 2001. Magistrado Ponente: María Victoria Sáchica Méndez. Expediente LAT- 188.

Sentencia C-400 del 10 de agosto de 1998. Magistrado Ponente: Alejandro Martínez CabaIlero. Expediente LAT-108.

Sentencia C-339 del 7 de mayo de 2002. Magistrado Ponente: Jaime Araujo Rentería. Expediente D- 3767.

Sentencia C-293 del 23 de abril de 2002. Magistrado Ponente: Alfredo Beltrán Sierra. Expediente D-3748.

Sentencia C-595 del 27 de julio de 2010. Magistrado Ponente: Jorge Iván Palacio Palacio. Expediente D-7977.

Sentencia C-596 del 27 de julio de 2010. Magistrado Ponente: Mauricio González Cuervo. Expediente D-7990. 
Sentencia C-742 del 15 de septiembre del 2010. Magistrado Ponente: Jorge Ignacio Pretelt Chaljub. Expediente D-8006.

Sentencia C-1007 del 6 de diciembre de 2010. Magistrado Ponente: Humberto Antonio Sierra Porto. Expediente D-8168.

Sentencia C-073 del 23 de 1995. Magistrado Ponente: Eduardo Cifuentes Muñoz. Expediente LAT-037.

Sentencia C- 671 del 28 de junio del 2001. Magistrado Ponente: Jaime Araujo Rentería. Expediente LAT- 191.

Sentencia C- 071 del 4 de febrero del 2003. Magistrado Ponente: Álvaro Tafur Gálvis. Expediente LAT- 222.

Sentencia C- 988 del 12 de octubre del 2004. Magistrado Ponente: Humberto Sierra porto. Expediente D- 4884.

\section{Sentencias de tutela}

Sentencia T-415 del 17 de junio de 1992. Magistrado Ponente: Ciro Angarita Barón. Expediente T- 101.

Sentencia T-299 del 3 de abril de 2008. Magistrado Ponente: Jaime Córdova Triviño. Expediente T-1.759.107.

Sentencia T-621 del 14 de diciembre de 1995. Magistrado Ponente: Eduardo Cifuentes Muñoz. Expediente T-76905.
Sentencia T-574 del 29 de octubre de 1996. Magistrado Ponente: Alejandro Martínez Caballero. Expediente T-100774.

Sentencia T-666 del 15 de agosto de 2002. Magistrado Ponente: Eduardo Montealegre Lynett. Expediente T-577130.

Sentencia T-966 del 8 de noviembre de 2002. Magistrado Ponente: Manuel José Cepeda Espinoza. Expediente T-621020.

Sentencia T-774 del 13 de agosto de 2004. Magistrado Ponente: Manuel José Cepeda Espinoza. Expediente T-755292.

Sentencia T-360 del 11 de mayo de 2010. Magistrado Ponente: Nilson Pinilla Pinilla. Expediente T-2520375.

Sentencia T-104 del 20 de febrero de 2010. Magistrado Ponente: Nilson Pinilla Pinilla. Expediente T-3228384.

Sentencia T- 960 del 6 de septiembre de 2001. Magistrado Ponente: Eduardo Montealegre Lynett. Expediente T-433061.

Sentencia T-1317 del 7 de diciembre de 2001. Magistrado Ponente: Rodrigo Uprimny. Expediente T-487462.

Sentencia T-1077 del 12 de diciembre de 2012. Magistrado Ponente: Jorge Ignacio Pretelt Chaljub. Expediente T-3.286.371. 